\title{
The Economic Legacy of General Velasco: Long-Term Consequences of Interventionism
}

\author{
César Martinellia ${ }^{\mathrm{a}, \boldsymbol{}}$, Marco Vega ${ }^{\mathrm{b}, \mathrm{c}}$ \\ ${ }^{a}$ George Mason University \\ $\bowtie$ cmarti33@gmu.edu "Corresponding author \\ ${ }^{\mathrm{b}}$ Banco Central de Reserva del Perú \\ ${ }^{\mathrm{c}}$ Pontificia Universidad Católica del Perú, Lima, Perú \\ $\bowtie$ marco.vega@bcrp.gob.pe
}

\begin{abstract}
We apply synthetic control methods to study the long-term consequences of the interventionist and collectivist reforms implemented by the Peruvian military junta of 1968-1975. We compare long-term outcomes for the Peruvian economy following the radical reforms of the early 1970s with those of two controls made of similar countries, one chosen in the Latin American region and another one chosen from the world at large. We find that the economic legacy of the junta includes sizable loses in GDP along two decades, beyond those that can be attributed to adverse international circumstances. The evidence suggests that those loses can be attributed both to a decline in capital accumulation and to a fall in productivity.
\end{abstract}

Article History: Received: March 42019 / Revised: December 92019 / Accepted: December 132019 Keywords: Output loss; Synthetic controls; Military nationalism; Populism; Collectivism; Peruvian Revolution.

JEL Classification: E52, E58, E62

\section{Acknowledgements}

We thank Roxana Barrantes, Roberto Chang, Alberto Chong, Kevin Grier, Gonzalo Pastor, Silvio Rendón, Bruno Seminario, and three anonymous referees for helpful comments. The authors alone are responsible for the views expressed in this paper. 


\section{Introduction}

The Peruvian military junta, presided by General Velasco from 1968 to 1975, represents a very unusual experiment in economic policy. The military engaged in a wide range of reforms restructuring ownership of economic assets in favor of the public sector and generally increasing the role of the state in the economy. Underpinning the policies was the belief - commonly associated with Latin American nationalism and populism - in the ability of a reform-minded state to orient business activity toward national goals and to eliminate foreign dependence via the adoption of command-and-control policies, including state-managed foreign trade. What is peculiar of the episode is that the military were able to implement the reforms untrammeled by institutional, political or legal constraints ${ }^{1}$. Moreover, the reforms were expected to be long-lasting, and to some extent they succeeded in being so, at least until pro-market reforms in the 1990s. Thus, the episode is a test-case for the economic policy recommendations of Latin American state-centered nationalist and populist creeds.

In this paper, we evaluate the long-term consequences of Velasco's reforms on GDP per capita, capital stock per capita, and total factor productivity. In particular, we compare the performance of the Peruvian economy with that of two synthetic controls made of similar countries - one chosen in Latin America and the other in the world at large. The idea of the controls is to isolate the effects of the policies from those of the changing international circumstances. From 1975, Peru, like other Latin American and developing economies, suffered almost two decades of declining terms of trade. In the 1980s, the region was shocked again by the drying out of international lending. Indeed, both synthetic controls exhibit stagnating GDP and capital stock per capita, and either stagnating or declining TFP, since the 1980s. The Peruvian economy does considerably worse than both controls in all cases. That is, the performance of the country under adverse circumstances was greatly hindered by the extent of state intervention in the economy that resulted from Velasco's reforms.

The synthetic control method was introduced in Abadie and Gardeazabal (2003) in the context of a study on the economic cost of conflict, and it was extended in Abadie et al. (2010) and Becker and Klößner (2018a). It has been used to study, among others, the effects of economic liberalization (Billmeier and Nannicini, 2013), the economic effects of natural disasters (Cavallo et al., 2013) and, closer to this paper, the economic consequences of Hugo Chavez regime (Grier and Maynard, 2016). The contrast with the case of Chávez is interesting. Grier and Maynard (2016) finds that the nationalist military regime of Chávez did worse than the controls while enjoying an export price boom, while we find that the economy under Velasco and his successors performed worse than the controls under unfavorable export prices ${ }^{2}$. In both cases, the economic consequences have been bleak.

Velasco took power in 1968, after deposing an elected president who did not deliver on his

\footnotetext{
${ }^{1}$ In fact, Velasco's regime was dubbed by social scientists as the "Peruvian experiment" (Lowenthal, 1975; McClintock and Lowenthal, 1983; Aguirre and Drinot, 2017) by the combination of very radical reforms implemented in fast succession by a government with an extraordinary degree of autonomy from society.

${ }^{2}$ According to Gott (2005, p. 95), Chávez visited Peru in 1974 as a young cadet, and claimed to have been inspired by the Peruvian example.
} 
campaign promises about land reform and a nationalist stance regarding a particularly irksome foreign oil enclave ${ }^{3}$. Velasco's regime ended in turn in 1975 with a palace coup, motivated in part by the deteriorating health of the dictator and in part by a looming balance-of-payments crisis $^{4}$. The successor military junta nominally shared the revolutionary project, but got bogged down by the crisis. Political power was transferred back to elected civilians in 1980-actually to the same president deposed by the military in 1968. Yet, there were important elements of continuity in economic regime under the successor elected administrations. Economic decision making remained in the hands of an expansive bureaucracy in public enterprises and government agencies $^{5}$. A half-hearted attempt at trade liberalization was abandoned in the early $1980 \mathrm{~s}^{6}$. A change in economic regime only came after the market-oriented reforms of the 1990s.

We use 1968-1975, 1968-1985, and 1968-1990 as alternative periods of analysis. The first one corresponds to the period of reforms under General Velasco. The second considers as well the successor military junta and the democratically elected administration that followed (19801985). The third one includes the "heterodox" democratically elected Garcia administration (1985-1990); this last choice is admittedly controversial since Garcia administration embarked in extreme fiscal and monetary mismanagement ${ }^{7}$. We find that GDP losses associated with the change in economic regime were around $10 \%$ by $1975,30 \%$ by 1980 and 1985 up to $50 \%$ of GDP by 1990 using either the Latin American or the world synthetic control. The gap with respect to the synthetic controls can be attributed both to lower productivity and slower capital accumulation. In terms of productivity, the loss in TFP was between $10 \%$ by the years 1980 and 1985 and reached $30 \%$ by 1990 . In term of capital accumulation, the loss in capital stock per capita reaches $30 \%$ in 1980 to 1990 . These performance results are stronger in the robustness case where we use a larger set of control countries.

We focus the analysis on the long term implications of Velasco's regime on economic growth, investment, and productivity. Of course, these are not the only metrics of interest. Some of the reforms implemented by the regime, and in particular land reform, were in the wish list of the major political parties before the 1968 coup and were likely very popular. The political regime before the 1968 coup was far from a full-fledged democracy. The electoral franchise was restricted to those deemed literate, but political representation was based on total population, which gave a strong hand to landed interests in the legislative. The concentration of land property was the historical result of the despoliation of the peasantry. When a new constitution was drafted by an elected assembly in 1978-1979 the old franchise restrictions were left firmly in the past. Indeed, one of the motivations of the junta was breaking the political and economic power of the traditional oligarchic families which were popularly perceived as a barrier to the modernization of the country. This was arguably accomplished.

\footnotetext{
${ }^{3}$ See the semi-official account of the coup by Zimmermann (1975).

${ }^{4}$ Zapata (2018)

${ }^{5}$ Lowenthal (1983), for instance, refers to the Peruvian state as "one of the strongest in Latin America". Fitzgerald (1983) calculates that the share of the corporate sector owned by the government or cooperatives was around $43 \%$ by 1975 , with $40 \%$ in the hands of domestic private business and the rest in the hands of foreign firms.

${ }^{6}$ See Nogues (1986).

${ }^{7}$ Martinelli and Vega (2018).
} 
One can trace a parallel between the politics of the state-centered reforms of 1968-1975 and the market-oriented reforms of the early 1990s. In both cases, the formal political institutions of the country were unable to process in a legal manner changes in the economic regime which at the time seemed ripe appeared urgent ${ }^{8}$. A politically negotiated reform process, respecting the constitution, would have made for a less clean experiment but would have likely eliminated some of the worse economic follies associated to the expansion of the role of the state in the economy.

The remainder of the paper is organized as follows. In section two we discuss the economic reforms of Velasco's regime, as well as their persistence through the 1970s and 1980s. In section three we summarize the synthetic control approach as applied in this paper. In section four we describe our data, empirical design, and estimated controls. In section five we present our results. In section six we explain the robustness exercise and in section seven we gather concluding remarks.

\section{The Peruvian Revolution}

General Velasco took power in Peru as head of a military junta in October 3 of 1968, after deposing an elected president and disbanding the congress. Peruvian military were disappointed with respect to the government stance regarding a foreign oil firm which notoriously managed an oil-rich area as an enclave ${ }^{9}$. They were disappointed also about the slow pace of the agrarian reform, promised by the civilian administration but perennially blocked or diluted in congress ${ }^{10}$. In October 9, the government expropriated and occupied the disputed oil fields. The military junta soon announced their aim of effecting a "vast process of transformation" with the purpose of ending Peru's "structural disequilibrium" and "foreign dependence"11.

The diagnosis of Peru's troubles and the reforms embraced by the military junta were inspired by military nationalism, by traditional Latin American structuralism, which prescribed land reform and industry promotion as means to eliminate internal "structural" barriers to growth, and by the "dependency school", a branch of Marxian thought in vogue in Latin America in the 1960s, which emphasized the deleterious effects of foreign ownership of assets on resource allocation decisions ${ }^{12}$. There was at the time a general interventionist spirit among development economists and practioners; the Little's report (Arthur D. Little, Inc., 1960), for instance, recommended an active industrial policy, making use of selective tariffs.

The economic regime embraced by the military was described by a sympathetic economist as "state capitalism". In his words,

\footnotetext{
${ }^{8}$ The parallel between Velasco and Fujimori's governments is one of the themes in the essays collected by Cameron and Mauceri (1997).

${ }^{9}$ Cotler (2018) discusses the ideological changes in the military that preceded the coup.

${ }^{10}$ Land reform was a historic demand of the left in Peru. Mariátegui (1928), for instance, considered that land reform should have been part of a liberal, capitalist transformation of Peru, that nonetheless had not happened. In the 1960s, belief in the need of a land reform in precisely that sense was widely shared in development circles (see e.g. Alianza para el Progreso, 1961).

${ }^{11}$ Velasco Alvarado (1972), speech to the 1969 meeting of CEPAL (United Nations Economic Commission for Latin America and the Caribbean).

${ }^{12}$ See e.g. Thorp and Bertram (1978, pp. 10-13).
} 
Historically, the process of transforming an export-led economy based on natural resources to one based on industry serving domestic markets requires an extensive restructuring of capital, involving change not only in the pattern of production (sectoral balance, input use, and so on) but also in the ownership of assets on the one hand and in the relationship between capital and labor on the other.

$\cdots$

By "state capitalism" in this context we mean that the state takes responsibility for organizing production and accumulation in the modern sector of the economy and that public ownership replaces private ownership in key branches. (Fitzgerald, 1983, p. 67).

Unlike other nationalist-military episodes in Latin America, such as Peron in Argentina or Chávez in Venezuela, Velasco's regime never enjoyed organized popular support. The junta shunned "the false participation" of traditional political parties by the "unity between people and armed forces"13. Reforms were introduced by decree, without any effective opposition. The military tolerated very little dissent, going to the length of confiscating most of the press. The relative autonomy of the regime relative to the society is one of the salient characteristics of the "Peruvian experiment" with revolution-from-above.

We summarize the reforms and their persistence after Velasco's regime in Table 1. A sweeping agrarian reform was announced in June 1969. The reform aimed to transfer most of arable land mainly to cooperatives and other collective entities under state tutelage. Land transfers continued during the so-called "second phase of the Peruvian Revolution", the successor military junta in 1976-1980. By 1980, $42 \%$ of arable land had been reallocated to collective entities and to peasants ${ }^{14}$. A database built in Espinoza et al. (2019) show that the great bulk of expropriations occurred in the period 1969-1980 and up 68\% of land transferred was private and in use. In parallel, state-owned enterprises with legal monopoly rights over trading in rice and other food staples and on agricultural inputs were created. Land re-privatization via breaking down the associative enterprises started with the return of a civilian administration in 1980. State-owned enterprises in food commerce were privatized in the early 1990s, after the abolition of state monopolies.

The Planning Office (INP) became an important government agency from 1969 on, acquiring budget authority, drafting directives for the spreading public enterprises, and producing a fiveyear national development plan with detailed production goals ${ }^{15}$. It lost influence after 1975, when the management of recurrent balance-of-payment crisis took center stage in the economic policy of the "second phase". The Planning Office was very active again during the "heterodox" civilian administration of 1985-1990. Pointedly, an economist from the Planning Office was recruited as general manager of the central bank in 1987; the central bank was seen as a harbinger of market-friendly ideas. The Planning Office helped organize the expansion of credit that preceded hyperinflation ${ }^{16}$. It was disbanded in 1992.

\footnotetext{
${ }^{13}$ Velasco Alvarado (1972), speech for the second anniversary of the revolution.

${ }^{14}$ Hunefeldt (1997).

${ }^{15}$ Cleaves and Pease-García (1983).

${ }^{16}$ See Martinelli and Vega (2018) on the Peruvian hyperinflation.
} 
Table 1

Revolutionary military junta's main economic reforms: 1968-1975.

\begin{tabular}{|c|c|c|c|}
\hline $\begin{array}{l}\text { Year } \\
\text { started }\end{array}$ & Reform & Policies & Persistence \\
\hline 1969 & $\begin{array}{l}\text { Agrarian } \\
\text { reform }\end{array}$ & $\begin{array}{l}42 \% \text { of arable land reallocated } \\
\text { to peasant cooperatives, state } \\
\text { monopoly in several food } \\
\text { staples }\end{array}$ & $\begin{array}{l}\text { land privatization since } 1980 \mathrm{~s}, \\
\text { state-owned enterprises } \\
\text { privatized in the } 1990 \mathrm{~s}\end{array}$ \\
\hline 1969 & $\begin{array}{l}\text { Economic } \\
\text { planning }\end{array}$ & $\begin{array}{l}\text { Planning Office (INP) } \\
\text { acquired budget authority } \\
\text { and set sectoral priorities }\end{array}$ & $\begin{array}{l}\text { INP influential in } 1985-1990 \text {, } \\
\text { disbanded in } 1992\end{array}$ \\
\hline 1969 & Trade & $\begin{array}{l}\text { import prohibition of goods } \\
\text { similar to domestic production, } \\
\text { export subsidies }\end{array}$ & $\begin{array}{l}\text { failed reversal in early } 1980 \mathrm{~s} \text {, } \\
\text { liberalization in the } 1990 \mathrm{~s}\end{array}$ \\
\hline 1970 & $\begin{array}{l}\text { Industrial } \\
\text { reform }\end{array}$ & $\begin{array}{l}\text { participation of labor in firm } \\
\text { management, creation of social } \\
\text { property sector }\end{array}$ & $\begin{array}{l}\text { scaling down of labor } \\
\text { participation in } 1977, \text { social } \\
\text { property never took off }\end{array}$ \\
\hline $1970 \mathrm{~s}$ & Banking & $\begin{array}{l}\text { nationalization of foreign } \\
\text { and some domestic banks }\end{array}$ & privatizations through the $1990 \mathrm{~s}$ \\
\hline 1969 & $\begin{array}{l}\text { Oil, } \\
\text { mining, } \\
\text { steel }\end{array}$ & $\begin{array}{l}\text { nationalization of foreign } \\
\text { interests, creation of state- } \\
\text { owned enterprises: PetroPerú, } \\
\text { MineroPerú, Centromín, } \\
\text { HierroPerú, SiderPerú }\end{array}$ & $\begin{array}{l}\text { partial privatizations through } \\
\text { the } 1990 \text { s }\end{array}$ \\
\hline $\begin{array}{l}1969 \\
1972\end{array}$ & $\begin{array}{l}\text { Telecom, } \\
\text { electricity, } \\
\text { water }\end{array}$ & $\begin{array}{l}\text { nationalization of various } \\
\text { companies, creation of } \\
\text { EntelPerú, ElectroPerú, } \\
\text { Sedapal }\end{array}$ & $\begin{array}{l}\text { privatizations of telecom and } \\
\text { electricity and decentralization } \\
\text { of water utilities through } \\
\text { the } 1990 \mathrm{~s}\end{array}$ \\
\hline 1974 & Fisheries & $\begin{array}{l}\text { nationalization of the sector } \\
\text { and creation of PescaPerú }\end{array}$ & privatizations through the 1990 s \\
\hline $\begin{array}{l}1970 \\
1974\end{array}$ & Media & $\begin{array}{l}\text { nationalization of newspapers } \\
\text { and TV channels }\end{array}$ & $\begin{array}{l}\text { devolution to previous owners } \\
\text { in } 1980\end{array}$ \\
\hline
\end{tabular}

Sources: See text; elaboration by the authors.

In terms of foreign trade, like in other Latin American countries, average tariffs were already high before the military took over. In addition, the military introduced in 1969 a list of forbidden imports, the National Registry of Manufacturing. Any industrial producer could call for the prohibition of imports of competitor goods from abroad. A complex web of import duties and export subsidies resulted from discretionary interventions. In addition, state-owned enterprises were granted monopoly status over imports of food staples ${ }^{17}$. There was a failed attempt to liberalize trade during the civilian administration of $1980-1985^{18}$, with trade liberalization happening in earnest in the 1990s.

The industrial reform decreed in 1969 altered labor-management relations in the industry, introducing worker participation in the administration and profits of industrial firms through the "industrial communities". In addition, a social property industrial sector, consisting of collectively owned enterprises, was supposed to be created and promoted. Industrial communities, which

\footnotetext{
${ }^{17}$ Torres (1982).

${ }^{18}$ In Nogues's (1986), account trade liberalization in the 1980s was attempted in an economy ridden with distortions and by a government with very little commitment toward it.
} 


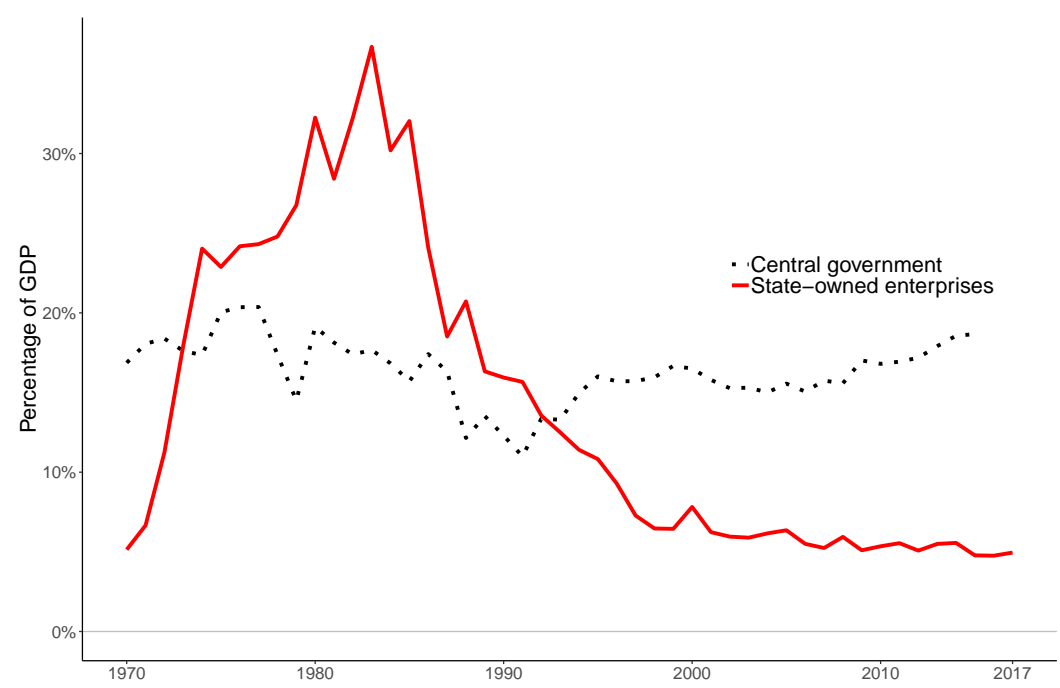

Source: Martinelli and Vega (2018).

Figure 1. Revenue of central government and state-owned enterprises.

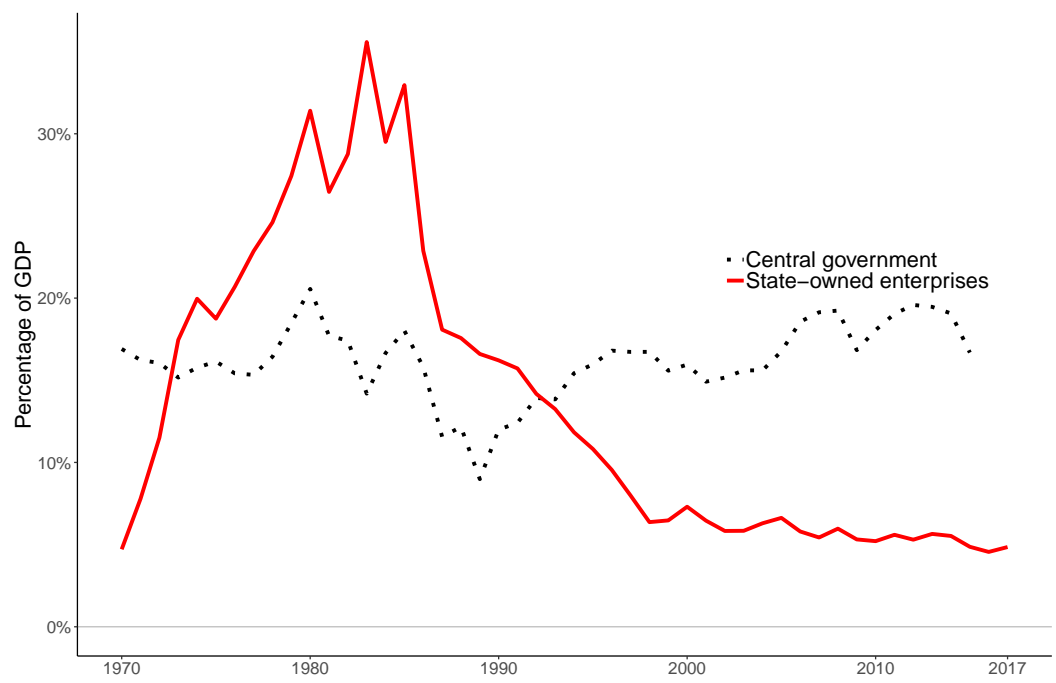

Source: Martinelli and Vega (2018).

Figure 2. Expenditure of central government and state-owned enterprises.

had a chilling effect on the private sector, were deactivated in the late $1970 \mathrm{~s}^{19}$, and the social property sector, one of the most utopian elements of the military reforms, never really took off ${ }^{20}$.

Starting in 1969, the military implemented a wave of nationalizations, including a takeover of most of the banking sector, the nationalization of major foreign oil and mining interests, and

\footnotetext{
${ }^{19}$ Abusada (1977).

${ }^{20}$ The education reform undertaken by the military in 1972 also had an important utopian element. It intended to create a "new type of man" and "raise political awareness" (Salazar Bondy, 1975). On a positive note, it also attempted to revalorize Peruvian indigenous languages and to use them in public education. It was resisted by teachers and parents, and rolled back in 1982.
} 
the nationalization of telecommunications, electricity and water services - all of them considered strategic sectors by the military. Large state-owned enterprises were introduced in each sector. A bad "El Niño" year and overfishing led to a crisis in the fishing industry in 1973; the response by the military junta was to nationalize the entire sector and create a state-owned enterprise with legal monopoly status. The nationalization of some TV channels and newspapers in 1970 and the nationalization of all remaining mass media in 1974 was likely primarily motivated by the desire to stifle dissent, and it was reversed as soon as power was returned to civilians.

State-owned enterprises created by the military junta in the "strategic" sectors, just like extensive state intervention in foreign trade, were going to be a lasting legacy. Figures 1 and 2 illustrate the expansion of state-owned enterprises in the aftermath of Velasco's reforms ${ }^{21}$. Privatizations of most of these state owned-enterprises happened during the $1990 \mathrm{~s}^{22}$.

\section{The Synthetic Control Approach}

In assessing the long-term effects of the military junta's reforms, the main problem is to define a counterfactual. The synthetic control method, introduced in Abadie and Gardeazabal (2003) and extended in Abadie et al. (2010) and Becker and Klößner (2018a), provides a way around this difficulty. Under this approach, a synthetic control is obtained by means of weighted combination of $J$ potential control countries. It is essential that the synthetic control approaches the treated unit in terms of the pre-treatment values. Following the notation of Abadie et al. (2010), if $J+1$ units (countries) are observed, the first unit is the treated country exposed to the policies, while others remain isolated to the policy and called the donor pool.

Outcomes are observed for $T$ periods and the policy starts in $T_{0}+1$. The observed outcome vector for each country is $Y_{j}=\left(Y_{j, 1}, \ldots, Y_{j, T_{0}}, \ldots, Y_{y, T}\right)$. The observed outcome is expressed as the sum of a treatment-free potential outcome $Y_{j, t}^{N}$ and the effect of the treatment $\alpha_{j, t}$, such that

$$
Y_{j, t}=Y_{j, t}^{N}+\alpha_{j, t} D_{j, t}
$$

and

$$
Y_{j, t}^{N}=\delta_{t}+\lambda_{t} \mu_{j}+\theta_{t} Z_{j}+\epsilon_{j, t}
$$

where $\delta_{t}$ is a time fixed effect, $Z_{j}$ is a time-invariant vector of predictors with time-varying coefficient $\theta_{t}, \mu_{j}$ is a time-invariant unobserved predictor with time-varying coefficients $\lambda_{t}, D_{j, t}$ is an indicator variable that takes the value of 1 for the treated unit after $T_{0}$ and is zero otherwise, and $\epsilon_{j, t}$ is an unobserved shock.

\footnotetext{
${ }^{21}$ Revenues and costs of state-owned enterprises are expressed as percentage of GDP for comparison purposes, though a more precise measurement of the size of the state in the economy would require to estimate the value added of state-owned enterprises. Of course, such calculation is fraught with difficulties.

${ }^{22} \mathrm{As}$ seen in the figures, both revenues and expenditures of state-owned enterprises started shrinking before the privatizations, as a result of the hyperinflation (Martinelli and Vega, 2018). The disorderly retreat of the state from the economy is described by Webb (1991).
} 
From periods 1 to $T_{0}$, the treatment-free potential outcome $Y_{j, t}^{N}$ should be similar to the observed outcome for both the treated and the control countries. For periods after $T_{0}$, the treatment-free counterfactual for the treated country $\left(Y_{1, t}^{N}\right)$ is unobserved. To estimate the treatment effect for the post-intervention periods, the synthetic control approach approximates the unobserved $Y_{1, t}^{N}$ by a synthetic control unit. This control is a weighted combination of potential controls that best approximates the relevant pre-intervention characteristics of the treated country. Let the weighting vector be $W=\left(w_{2} \ldots w_{J+1}\right)^{\prime}$, where the elements are the contribution of each control country to the synthetic control unit. The weights obey the constraints $w_{j} \geq 0$ and $w_{2}+\ldots+w_{J+1}=1$. The estimator of the counterfactual comes from a linear combination of the observed outcomes of the potential control regions: $\hat{Y}_{1, t}^{N}=\sum_{j=2}^{J+1} w_{j} Y_{j, t}$. The estimated treatment effect for the treated country for each time period after $T_{0}$ is $\hat{\alpha}_{1, t}=Y_{1, t}-\hat{Y}_{1, t}^{N}$.

According to Abadie et al. (2010), if the weighted value of the observed covariates and pretreatment outcomes for the control pool equals those of the treated region, $Z_{1, t}=\sum_{j=2}^{J+1} w_{j} Z_{j, t}$ and $Y_{1, t}^{N}=\sum_{j=2}^{J+1} w_{j} Y_{j, t}^{N}$, for the periods $t=1, \ldots, T_{0}$ and the outcome is a linear function of observed and unobserved potential confounders, then $\hat{\alpha}_{1, t}$ is an approximately unbiased estimator of $\alpha_{1, t}$.

The vector $W^{*}$ is chosen to minimize the distance in the observed and unobserved confounders between the treated and the synthetic control country, measured before the intervention. The distance is measured according to the metric $\sqrt{\left(X_{1}-X_{0} W\right)^{\prime} V\left(X_{1}-X_{0} W\right)}$ where $X_{1}$ is a $k \times 1$ vector including $k$ covariates and pre-treatment outcomes for the treated region, while $X_{0}$ is the corresponding $k \times J$ matrix of the control countries. $V$ is a $k \times k$ positive definite diagonal matrix which assigns weights according to the relative importance of the covariates and the preintervention outcomes. The choice of variables in $X_{0}$ and $X_{1}$ vectors needs to be justified on economic grounds. Abadie and Gardeazabal (2003) and Abadie et al. (2010) propose a procedure to determine the $V$ matrix among all positive definite and diagonal matrices such that the mean squared prediction error (MSPE) of the outcome variable is minimized over some set of preintervention periods.

\section{Empirical Design and Estimated Controls}

We select as outcomes of interest GDP per capita, capital stock per capita and TFP. Predictors are listed in Table 2. Data sources and construction of the variables is explained in the appendix. In every case, data is available since 1960.

We work with two different control groups. The first comprises countries in the Latin America and the Caribbean region, henceforth LAC countries. These countries have similar political and cultural characteristics to the treated country ${ }^{23}$. This group of countries make up our benchmark case. To perform a robustness check, we use a second control group that comprises all the countries in the world with data available to perform the exercise. Countries in the control group should have GDP, TFP and capital stock data from at least 1953 onwards. Control groups are detailed in the appendix.

\footnotetext{
${ }^{23} \mathrm{~A}$ control group with countries in the same region as the treated unit is also used by Billmeier and Nannicini (2013) in a study of economic liberalization episodes.
} 
Table 2

Variables.

\begin{tabular}{l}
\hline Outcomes \\
\hline Log of GDP per capita \\
Log of capital stock per capita \\
Log of TFP \\
\hline Predictors \\
\hline Openness \\
Share of gross capital formation at current PPP \\
Log of terms of trade \\
Labor force participation \\
Human capital index \\
General government investment \\
Private investment \\
\hline
\end{tabular}

In both control groups we leave out Argentina, Chile and Jamaica, which had extreme policy variations during the period, including similar policies to Peru in the case of Chile and Jamaica in the early 1970s. An important issue is the determination of the treatment year. The radical policy shift in Peru arguably started with the 1968 coup but the reforms were introduced in 19691974. In successive years policy swings and external factors introduced confounding factors. We explore different treatment starting dates in the appendix. The pre-treatment predictor fitness criteria as well as average post treatment losses favors a treatment year before 1974 in almost all cases, and preferably in the years 1970, 1971, or 1972. Statistically, the starting year of treatment seems to be 1972 which happens to be the middle point of General Velasco's term.

For the following exercises we use 1970 as starting year, which follows from the main economic reforms described in section 2 and provides a conservative estimation versus 1972. We use the set of predictors in Table 2 to estimate weights to approximate mean performance in the period 1960-1969, and use those weights to construct the synthetic controls. We calculate two types of weights; ADH weights are based on the standard procedure documented in Abadie et al. (2010) while the efficient BK weights are based on Becker and Klößner (2018a). Both methods are run in the R packages provided respectively by Abadie et al. (2011) and Becker and Klößner (2018b).

The estimated weights for the LAC and the world control groups are reported in tables 3 and B.2 respectively. In the efficient BK weights for GDP using the LAC control group, Bolivia, Brazil and Mexico account for $83 \%$ of synthetic Peru. With respect to TFP and capital stock per capita, Costa Rica, the Dominican Republic and Venezuela are also large contributors. In the efficient BK weights for GDP using the world control group, Uruguay, Egypt and Trinidad and Tobago account for $74.2 \%$ of synthetic Peru. With respect to TFP and capital stock per capita, Bolivia, Brazil and Venezuela are also large contributors. The same set of countries appears as large contributors in the $\mathrm{ADH}$ weights. 
Table 3

Estimated synthetic control weights (LAC control group).

\begin{tabular}{lrrrccc}
\hline Country & \multicolumn{2}{c}{ GDP } & \multicolumn{2}{c}{ TFP } & \multicolumn{2}{c}{ Capital } \\
\cline { 2 - 7 } & ADH & BK & ADH & BK & ADH & BK \\
\hline Bolivia & 2.3 & 24.1 & 0.1 & 14.2 & 32.7 & 28.4 \\
Brasil & 1.8 & 17.4 & 35.0 & 29.7 & 0.6 & 0 \\
Colombia & 1.2 & 0.0 & 0.1 & 0 & 0.05 & 0 \\
Costa Rica & 37.6 & 0.0 & 51.5 & 0 & 24.6 & 37.7 \\
Dominican R. & 1.6 & 8.0 & 0.3 & 0 & 13.0 & 12.8 \\
Ecuador & 1.0 & 0.0 & 0.1 & 0 & 0.03 & 0 \\
Guatemala & 1.2 & 0.0 & 8.8 & 56.0 & 1.0 & 0 \\
Honduras & 1.4 & 0.0 & NA & NA & NA & NA \\
Mexico & 15.6 & 41.0 & 3.9 & 0 & 16.6 & 4.6 \\
Panama & 1.6 & 0.0 & NA & NA & NA & NA \\
Paraguay & 2.4 & 0.0 & NA & NA & NA & NA \\
Trinidad and T. & 21.7 & 0.0 & NA & NA & 0.02 & 0 \\
Uruguay & 10.7 & 0.0 & 0.01 & 0 & 0.03 & 0 \\
Venezuela & 0.03 & 9.6 & 0.1 & 0 & 11.4 & 16.5 \\
\hline
\end{tabular}

Note: NA means that data is not available to estimate the weight.

\section{Results}

\subsection{Effects on GDP}

Figures 3a and 3b illustrate the estimated effects of the change in economic regime of 19681975 over GDP per capita using the LAC control group. Note that synthetic Peruvian GDP does stagnate and fall in the 1980s. This reflects the negative external and supply shocks that affected Peru as well as Latin American and Caribbean countries alike. The drop in synthetic GDP in 1982 is clearly visible. Observed GDP stagnates sooner than its synthetic and falls sharply towards the end of the 80's.

Hence, observed GDP is always below its synthetic after the implementation of Velasco's radical policy shift. Just at the end of the first phase of the military regime in 1975, observed GDP is $10 \%$ lower than synthetic GDP. But, as mentioned above, the core of reforms persisted across the following three administrations. By 1980, ten years after the implementation, the negative gap reached 30\%. After the next five years the negative 30\% GDP gap persisted. Recall that during this 1980-1985 period the synthetic also falls.

The strongest effect occurs towards 1990 (see Figure 3c), when GDP dropped to only about $50 \%$ of the synthetic control. However this 1990 result may not be entirely attributed to the Velasco's treatment. Even though its core reforms persisted and shaped the fabric of economic structure up to 1990, heterodox populism of the 80's might have worsen the observed 1990 outcome. Nevertheless, it is key to highlight that the negative $50 \%$ gap compares to commonly used simple loss estimations of output loss brought about by radical policy shifts. The first is the loss relative to a previous last GDP peak, which was recorded in 1974. The loss relative to 1974 is $37 \%$. The second loss estimation can be performed by projecting the GDP trend observed in 1969 up to 1990 . The loss relative to this trend counterfactual is about $81 \%$. 


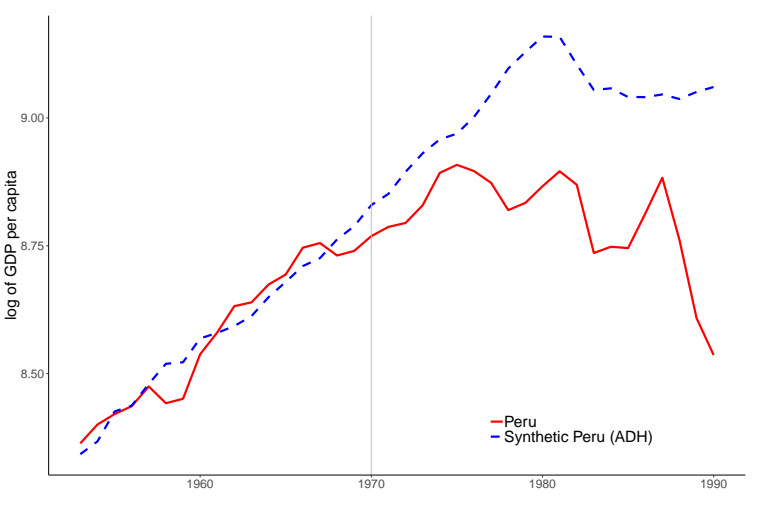

(a) ADH case.

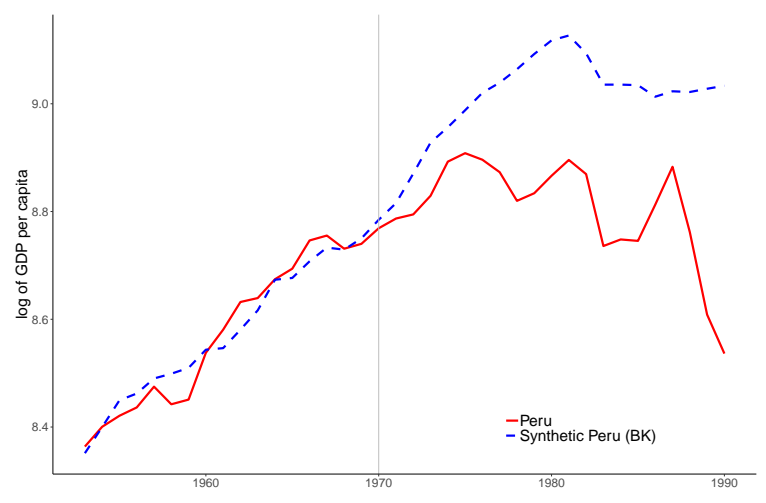

(b) BK case.

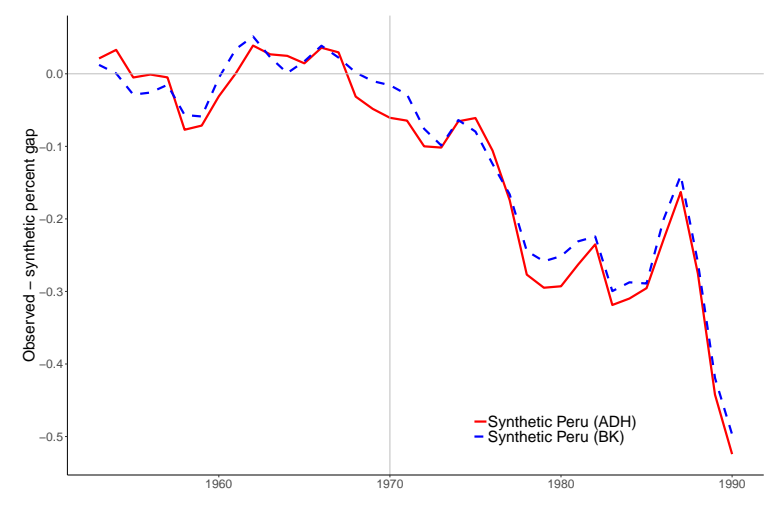

(c) Observed vs synthetic Peru GDP gap.

Figure 3. GDP performance in Peru 1953-1990 (LAC control group).

In Figure 3 we see that both methods provide evidence that the military junta's reforms, though possibly well-meaning, had persistent negative consequences. The GDP loss against both synthetic counterfactuals in every case is stark.

Significance of estimates: Following Abadie and Gardeazabal (2003), we also performed placebo exercises for the two estimation methods. We run the synthetic control method for each country in the control group, one by one, as if it received the treatment. Figure 4 shows the trajectories of country GDP gaps before and after the treatment for the LAC control group. Countries with higher gap variance before treatment are omitted from both figures.

The Peruvian fall in GDP per capita appears to be in effect attributed to the specific radical policy shift observed in the country. Honduras and Bolivia also experienced extreme output falls albeit unrelated to the sort of policies implemented in Peru. The downfall in Honduras and Bolivia is stronger in the 80's due to regionwide debt problems that hit specially these two countries. Bolivia accumulated too much debt and had exchange rate and balance of payment crisis after a boom period (Kehoe et al., 2019). The case of Honduras is also related more to how deeply it was hit by the external shocks of the 1980's due to a vulnerable economic position.

Figure 5 reports the ratios between the post-treatment root mean squared prediction error (RMSPE) and the pre-treatment RMSPE for Peru and all the donor countries. Here the pre- 


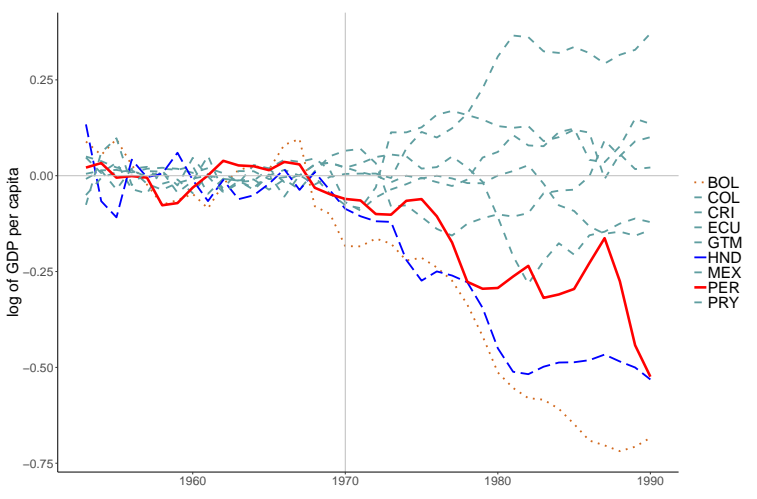

(a) ADH case.

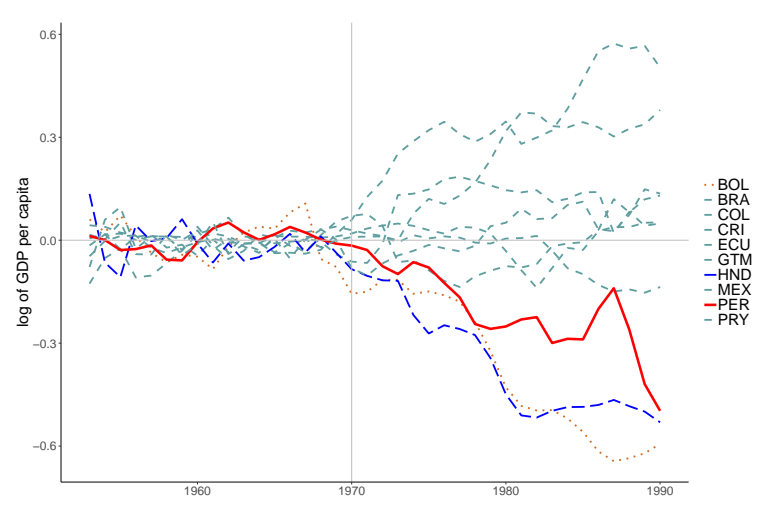

(b) BK case.

Figure 4. GDP gaps against synthetic counterfactuals: placebo treatments (LAC).

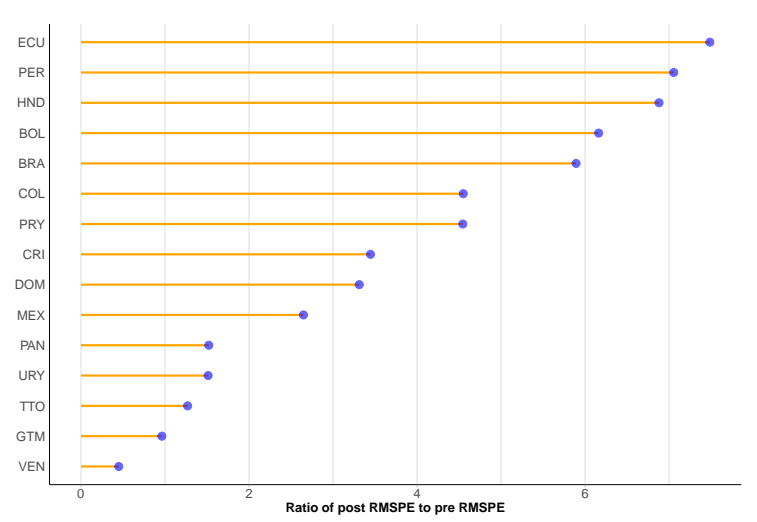

(a) $\mathrm{ADH}$ case.

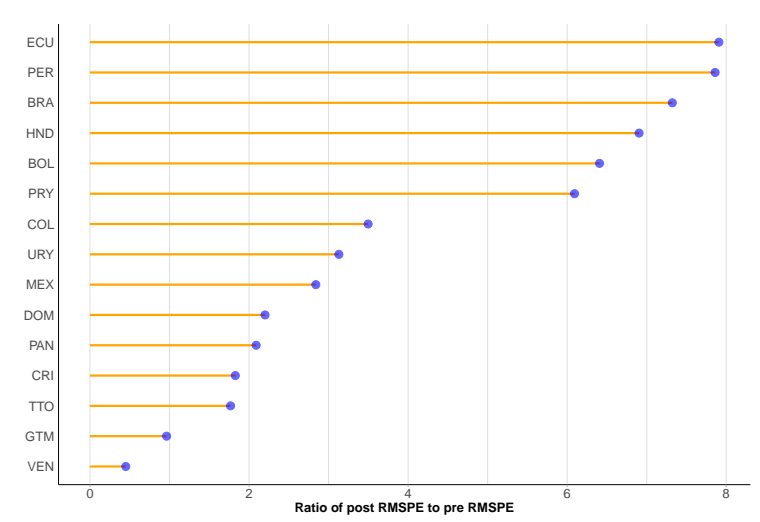

(b) BK case.

Figure 5. GDP: Root mean squared prediction error (RMSPE) ratios.

diction error comes from the difference between the observed GDP and its counterfactual. We expect the prediction error to be small in the pre-treatment period and to be large in the posttreatment period. In our analysis, Honduras and Bolivia for example have large post RMSPE as seen in Figure 4 but they also have a large pre-intervention RMSPE which means that the synthetic does not reproduce pre-treatment GDP in Honduras and Bolivia well enough.

As in Abadie et al. (2015), we divide the post-treatment RMSPE by the pre-treatment RMSPE. Peru and Ecuador have the highest ratio reaching up to 8 times. This means that, giving this set of countries, the probability of obtaining a ratio as high as high as 8 is only about 0.13 and therefore there is support to conclude that the economic effects of Velasco's radical policies on GDP are strongly negative. Indeed, it is difficult to have obtained this outcome just by chance.

\subsection{Effects on total factor productivity}

The growth accounting exercise performed in Martinelli and Vega (2018) supports the idea that the radical reforms of the 1970s led to a misallocation of resources that led to a heavy 
drop in total factor productivity. The reforms affected total factor productivity possibly via a crowding out of private investment stemming from increased participation of public investment that turned out less efficient. The usual sources of inefficiency of the public sector, soft budget constraints and reduced monitoring, were likely compounded by the authoritarian nature of military rule in 1968-1980 24 . Productivity in the private sector may have been affected by the web of taxes and subsidies, discretionary intervention, uncertainty about property rights, and policy uncertainty ${ }^{25}$.

To shed more light on the dynamics of total factor productivity, we perform the synthetic control approach on TFP levels at current PPP (ctfp) as provided by the Penn World Table (PWT). This variable is measured relative to USA TFP. We consider this variable is better suited to make cross-country comparisons than the alternative TFP at constant national prices set to unity at 2011 for all countries.

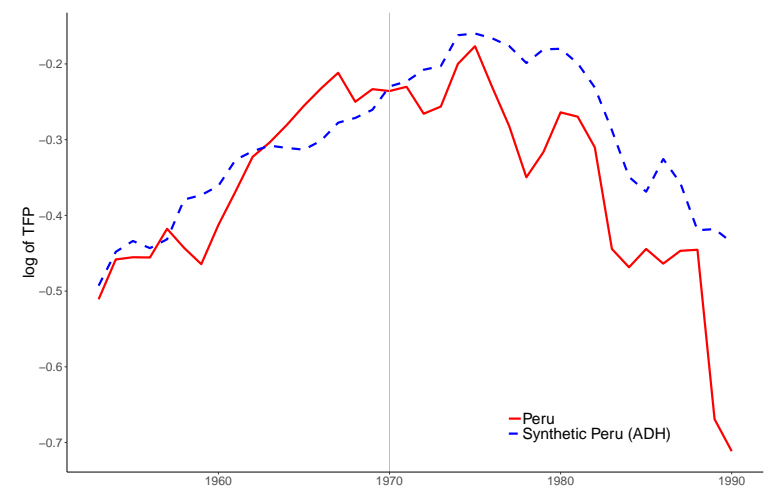

(a) $\mathrm{ADH}$ case.

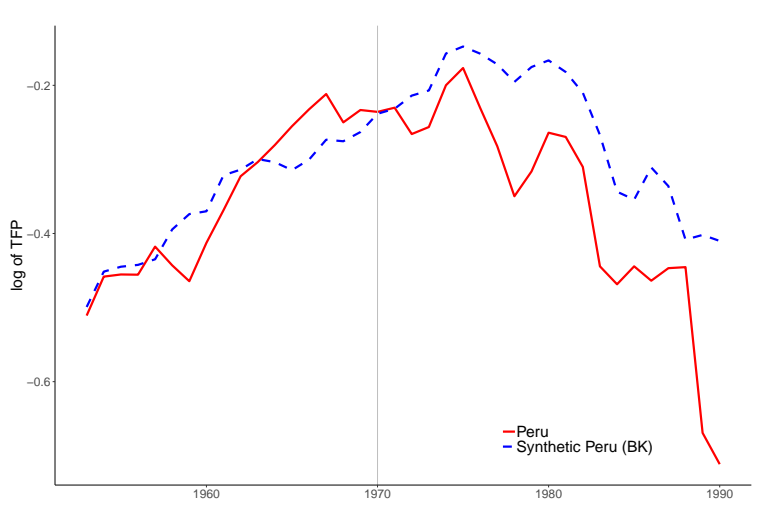

(b) BK case.

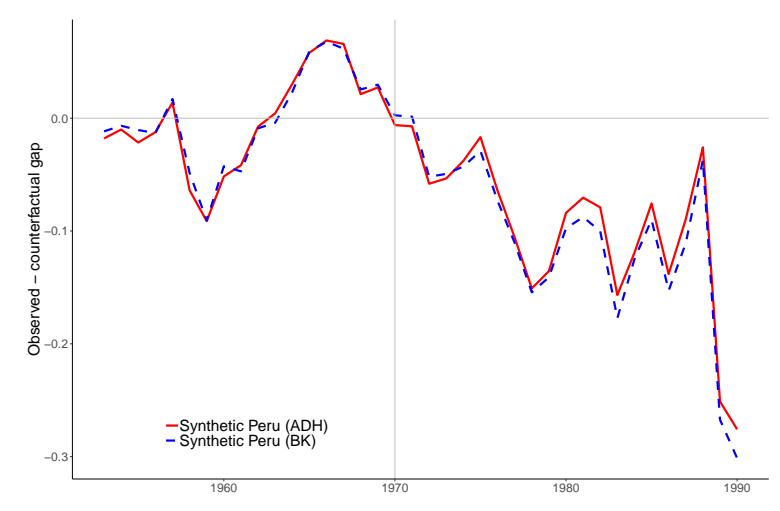

(c) Observed vs synthetic Peru GDP gap.

Figure 6. TFP performance in Peru 1953-1990 (LAC control group).

\footnotetext{
${ }^{24}$ Quiroz (2008, p. 330-332) notes that the watchdog role of the free press was severely curtailed, limiting the uncovering of corruption scandals. The largest such scandals involved the state enterprise in charge of food staples and the state fisheries enterprise, run by generals close to Velasco.

${ }^{25} \mathrm{An}$ example is that of "fake" exports engineered to benefit from export subsidies, particularly during the "second phase" (Quiroz, 2008, p. 333). In the words of Schydlowsky and Wicht (1983), "Public officials believed that by establishing 'controls' they would effectively direct the economic activity of the country; in fact they made it only more complicated, slower, and more inclined than ever to by-pass regulations."
} 
The results for the LAC control group are shown in Figure 6. Figures $6 \mathrm{a}$ and $6 \mathrm{~b}$ show the TFP path under both methods, the synthetic TFP mildly grows over the first years of the 1970s to achieve a plateau and then to fall down during the 1980s. Instead, the observed TFP does not increase during the first half of the 1970s and starts falling sharply after 1975.

The gap between the observed and both synthetic TFP levels are shown in Figure 6c. Even though the gap is negative after the Velasco treatment, its size is of the same order of magnitud as that observed in the pre-treatment gap. This might reflect a poor performance of the predictors during the pre-treatment period or else, that the treatment did not push PTF further down in addition to the negative external factors that hit LAC countries in the period.

In section 6 we perform the same exercise but with a larger control group. The result provides more evidence on the negative effect of the reforms on total factor productivity.

Significance of TFP estimates: The evidence that the Velasco treatment did have a negative effect on total factor productivity is weak in the benchmark case with LAC controls. Figure 7 shows the placebo trajectories of country TFP gaps before and after the treatment for the LAC control group. As before, countries with higher gap variance before treatment are omitted from both figures. The negative gap result is somewhat more visible in the BK case where Costa Rica and Peru have the worst performance (The Dominican Republic is not plotted because it did pass the variance threshold).

Figure 8 reports the ratios between the post and the pre-treatment RMSPE for Peru and all the donor countries. The figure reveals that the negative effect of the treatment in Peru is rather weak. The post-treatment RMSPE is just a bit more than the pre-treatment RMSPE. In other words, just by looking at the small set of LAC country predictor variables, we are not able to have a good prediction for the pre-treatment period.

The robustness exercise of section 6 shows more significance to the negative effect of Velasco's reforms on total factor productivity.

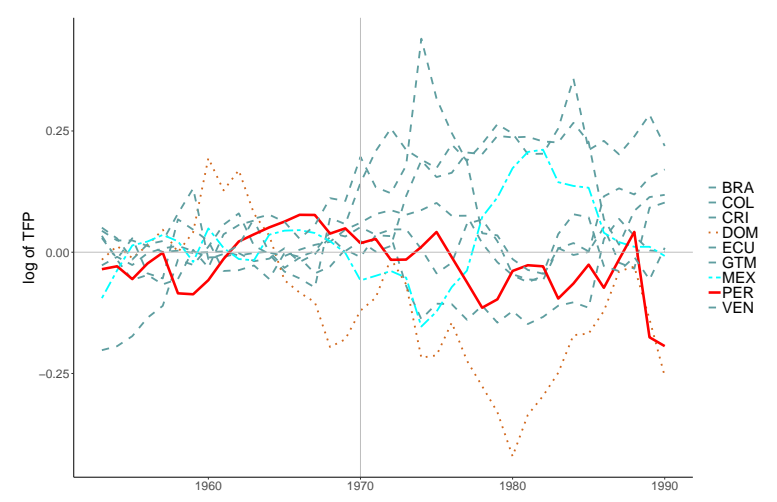

(a) $\mathrm{ADH}$ case.

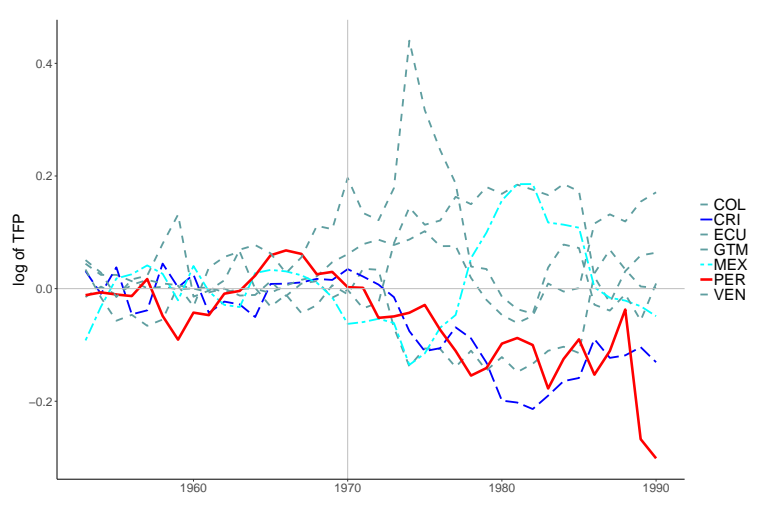

(b) BK case.

Figure 7. TFP gaps against synthetic counterfactuals: placebo treatments (LAC). 


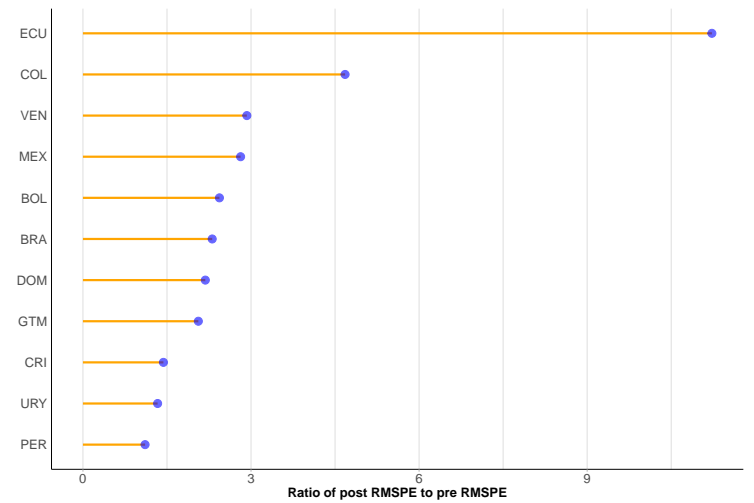

(a) ADH case.

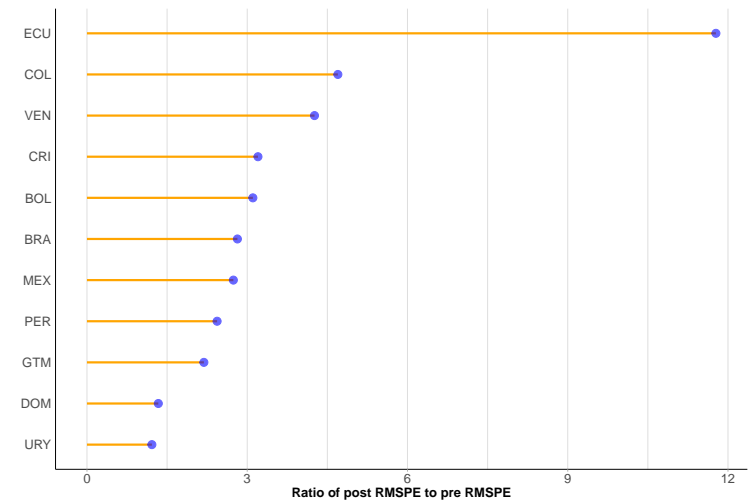

(b) BK case.

Figure 8. TFP: Root mean squared prediction error (RMSPE) ratios.

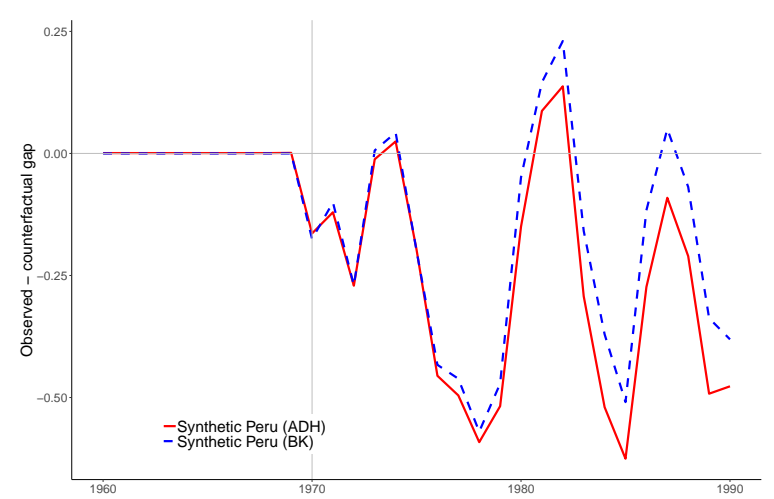

(a) Private investment.

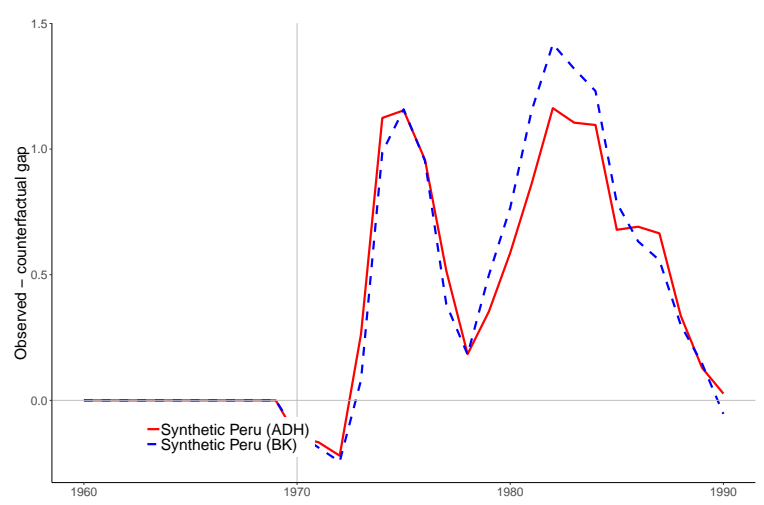

(b) Public Investment.

Figure 9. Effect on private and public investment (LAC control group).

\subsection{Effects on Capital Stock per Capita}

Velasco's regime attempted to put the state "at the center of capital accumulation in a market economy" (Fitzgerald, 1983). Foreign borrowing and redirecting resources from the domestic financial sector served to finance an increase in pubic investment in oil and mining. Capital accumulation in the private sector may have been affected by the usual crowding out, by uncertainty about property rights, and by policy uncertainty. In turn, public investment after the first few years of military rule may have been affected by recurrent fiscal difficulties and the deleterious effects of stop-and-go policies ${ }^{26}$.

Figure 9 shows the effect of the radical reforms on private and general government investment. Private investment tends to have a negative gap while public investment has a positive gap. A crowding out effect of private investment is clear from the figure. The lost in private investment tends to be about $50 \%$ while the increase in public investment reaches up to $100 \%$. Official figures from the central bank of Peru show that the ratio of private to public gross investment went from 3 in the 60's to about 1.5 in 1976. So, overall, this channel tended to reduce capital stock.

\footnotetext{
${ }^{26}$ Gonzales de Olarte and Samamé (1991).
} 


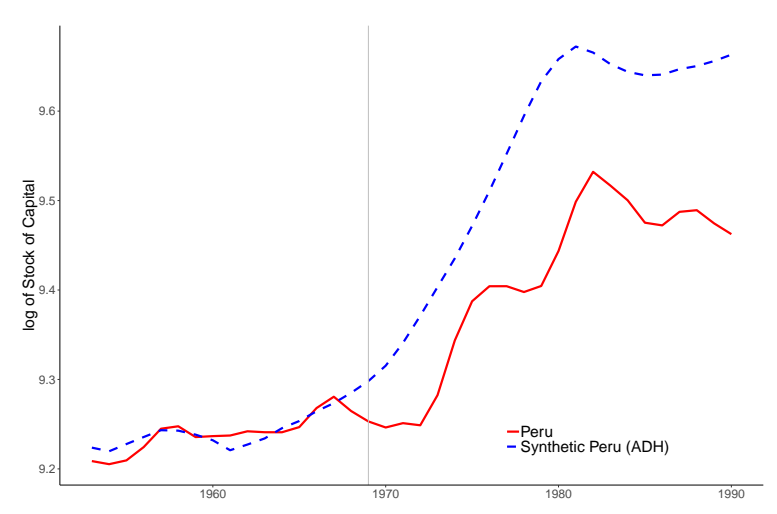

(a) $\mathrm{ADH}$ case.

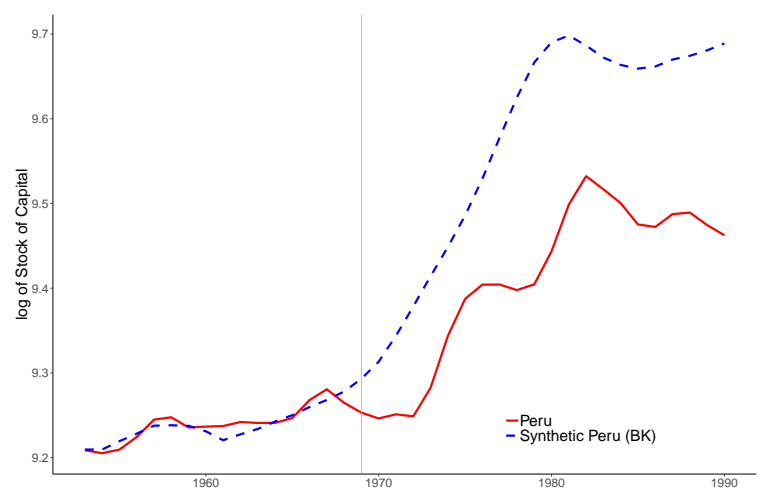

(b) BK case.

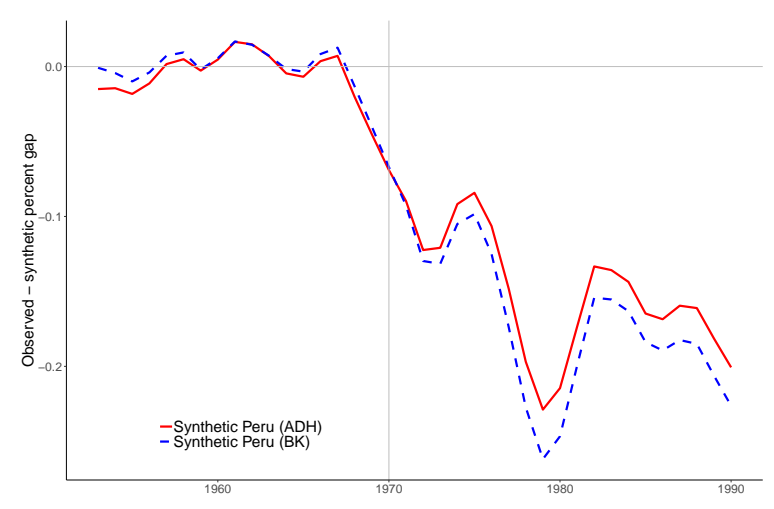

(c) Observed vs synthetic Peru capital stock gap.

Figure 10. TFP performance in Peru 1953-1990 (LAC control group).

Figure 10 illustrates the observed behavior of the capital stock per capita against that of the LAC counterfactual. Under both methods, the synthetic capital stock grows vigorously up until 1980 and then stops growing. In fact, capital stock stagnated in basically all Latin American economies during the 1980s due to adverse external factors such as higher world interest rates and the related debt default problems that arose in the region. In Peru, in contrast, capital stock per capita starts falling just after 1969. The loss in capital stock per capita measured at 1980, 1985 and 1990 according to this counterfactual was near $20 \%$.

Significance of capital stock estimates: Figure 11 shows the placebo trajectories of country capital stock gaps before and after the treatment for the LAC control group. Again, countries with higher gap variance before treatment are omitted from both figures.

Figure 12 reports the ratios between the post and the pre-treatment RMSPE for Peru and all the donor countries. The figure reveals some evidence of negative effect of the Velasco treatment in Peru o the capital stock. The post-treatment RMSPE is between 10 and 20 times the pre-treatment RMSPE. The associated p-value for the $\mathrm{ADH}$ and $\mathrm{BK}$ case are 0.42 and 0.25 respectively.

Overall, the benchmarks results under the LAC control group show a strong GDP effect, a very weak effect on TFP and a mild effect on capital stock. 


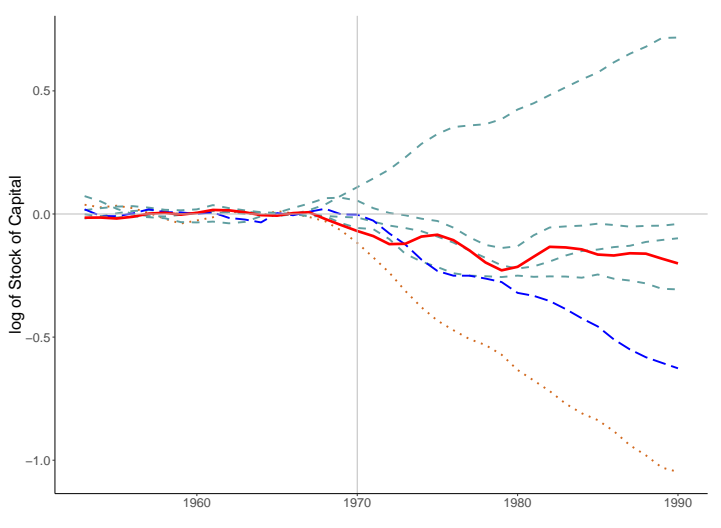

(a) $\mathrm{ADH}$ case.

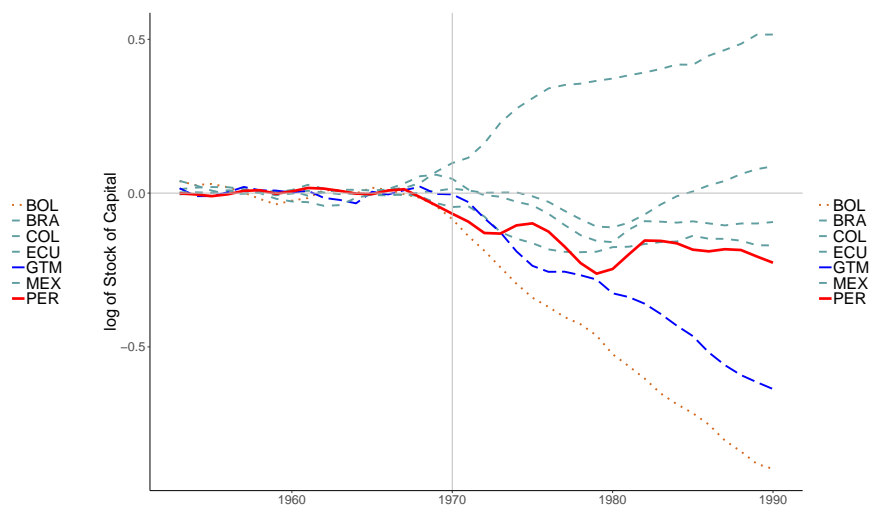

(b) BK case.

Figure 11. TFP gaps against synthetic counterfactuals: placebo treatments (LAC).

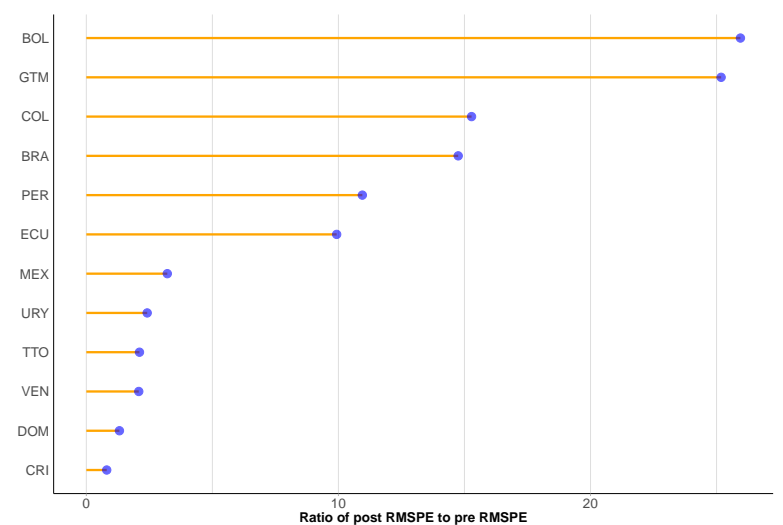

(a) ADH case.

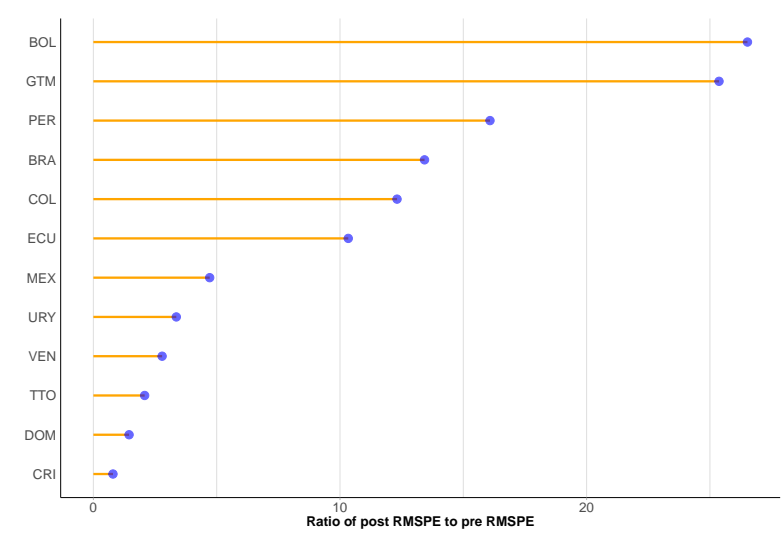

(b) BK case.

Figure 12. Capital stock: Root mean squared prediction error (RMSPE) ratios.

\section{Robustness}

We use a broader set of world countries to seek for the appropriate donor countries. Figure B.1 in the appendix illustrates the effects on per capita GDP, total factor productivity and per capita capital stock. In all three cases, the effect is negative. In turn, Figure B.2 shows the placebo runs for each country in the broader control group. The negative effects in Peru are among the strongest. Last, Figure B.3 depicts the ratios of post RMSPE to pre RMSPE. In all cases, the ratio corresponding to Peru stands out in the top group.

Table 4 shows the summary of the effects by each five-year period after treatment. The effects are similar to those obtained with the benchmark LAC control group. For each variable and weight estimation method, we also report the p-values as proposed in Abadie et al. (2015), which are relatively close to cero and thus, provide some evidence of the significance of the overall effects. 
Table 4

Summary of effects of reforms with the world control group.

\begin{tabular}{ccccccc}
\hline \multirow{2}{*}{ Year } & \multicolumn{2}{c}{ GDP gap } & \multicolumn{2}{c}{ TFP gap } & \multicolumn{2}{c}{ K gap } \\
\cline { 2 - 7 } & ADH & BK & ADH & BK & ADH & BK \\
\hline 1975 & -0.04 & -0.04 & -0.01 & -0.005 & -0.1 & -0.1 \\
1980 & -0.3 & -0.3 & -0.04 & -0.05 & -0.3 & -0.3 \\
1985 & -0.4 & -0.4 & -0.1 & -0.2 & -0.3 & -0.3 \\
1990 & -0.6 & -0.7 & -0.3 & -0.3 & -0.4 & -0.3 \\
p-value (1990) & 0.17 & 0.13 & 0.23 & 0.44 & 0.13 & 0.3 \\
\hline
\end{tabular}

\section{Concluding Remarks}

The Peruvian military junta of 1968-1975 embarked in an ambitious attempt to refashion the economy of the country away from traditional laissez-faire policies by increasing the size of the public sector through an extensive program of nationalization and collectivization, and by command-and-control policies over the private sector. Some of military junta reforms, and in particular the importance of state-owned enterprises in the economy, were persistent.

The military junta's reforms were influenced by import substitution industrialization ideas popularized by CEPAL, by military nationalism, by the so called "dependency school", and by the general interventionist spirit of development economics at the time. All these pointed in the direction of state intervention in the economy to remove barriers to development and to correct and orient economic agents. The authoritarian nature of military rule allowed the implied policies to be taken to extremes.

The aftermath of the military junta was marked by a fall in GDP per capita until the marketoriented reforms of the 1990s. The external environment was unfavorable during the period, with terms of trade declining from the 1970s to the early 1990s, begging the question as to what extent the protracted recession was caused by policy and to what extent by the environment. To answer this question, we construct synthetic controls using a sample of Latin American countries and by a world sample.

Empirical exercises using synthetic controls provide evidence that the change in economic regime experienced by the country in the early 1970s had negative effects on GDP per capita, productivity and capital stock well beyond those of similar countries. That is, the recession was considerably worsened by the change in economic regime. The fall in productivity is consistent with increased misallocation due to extensive and arbitrary intervention in the economy, while the fall in capital accumulation is consistent with the observation of crowding out and from policy uncertainty and uncertainty over property rights.

Looking back, it is hard to miss the fundamental mistrust in market allocations by the military government and their advisors, compounded by wishful thinking, as an important reason behind the economic failure of the reforms. Similar mistrust in market allocations combined with wishful thinking would be a pattern repeated by the Garcia administration in 1985-1990. In line with the long-term reviews of the Peruvian economy by Sheahan (1999) and Hunt (2011), we think of the period from the 1960s to the 1980s as a stage in the (unfinished) process of the Peruvian society to find a path to growth and a better distribution. 


\section{Appendix A. Variables}

Log of real GDP per capita, log of capital stock per capita and log of TFP are calculated using data from the Penn World Table version 9.0 [PWT] at constant 2011 national prices (in millions of USD); data for population is also obtained from the PWT. Openness is defined as exports plus imports as a share of output-side real GDP at constant 2011 national prices (in millions of USD). The corresponding series for exports and imports at the PWT are csh_x and $c s h \_m$; note that $c s h \_m$ has a negative sign. Terms of trade is taken from DataMarket.com. Labor force participation is obtained from the PWT as the ratio of numbers of persons engaged in labor (emp) divided by total population. The share of gross capital formation at constant PPP and the human capital index are obtained from the PWT. For private and public investment we take the variables igov_rppp that stands for the general government investment (gross fixed capital formation) and variable ipriv_rppp that stands for private investment (gross fixed capital formation). Both latter variables are expressed in billions of constant 2011 international dollars and are obtained from the Investment and Capital Stock Dataset (1960-2017) at the IMF.

\section{Appendix B. Robustness Exercise}

The world control group is composed of every country in the PWT with data available for 1960-1990; see Table B.1. The Latin American and Caribbean control group is the subset from the region in Table B.1. 
Table B.1

World control group.

\begin{tabular}{|c|c|c|c|c|c|c|c|c|c|}
\hline \multicolumn{5}{|c|}{ Developed } & \multicolumn{5}{|c|}{ Developing } \\
\hline & Europe & & Other & & $\begin{array}{l}\text { Latin America and } \\
\text { the Caribbean }\end{array}$ & & Asia & & Africa \\
\hline 1 & Austria & 19 & Australia & 24 & Bolivia & 36 & China & 46 & D.R. of the Congo \\
\hline 2 & Belgium & 20 & Canada & 25 & Brazil & 37 & India & 47 & Egypt \\
\hline 3 & Denmark & 21 & Japan & 26 & Colombia & 38 & Pakistan & 48 & Ethiopia \\
\hline 4 & Finland & 22 & New Zealand & 27 & Costa Rica & 39 & Philippines & 49 & Kenya \\
\hline 5 & France & 23 & United States & 28 & Dominican Republic & 40 & Sri Lanka & 50 & Morocco \\
\hline 6 & Germany & & & 29 & Ecuador & 41 & Thailand & 51 & Nigeria \\
\hline 7 & Greece & & & 30 & Guatemala & 42 & Turkey & 52 & South Africa \\
\hline 8 & Iceland & & & 31 & Jamaica & 43 & Republic of Korea & 53 & Uganda \\
\hline 9 & Ireland & & & 32 & Mexico & 44 & Taiwan & & \\
\hline 10 & Italy & & & 33 & Trinidad and Tobago & 45 & Israel & & \\
\hline 11 & Luxembourg & & & 34 & Uruguay & & & & \\
\hline 12 & Netherlands & & & 35 & Venezuela & & & & \\
\hline 13 & Norway & & & & & & & & \\
\hline 14 & Portugal & & & & & & & & \\
\hline 15 & Spain & & & & & & & & \\
\hline 16 & Sweden & & & & & & & & \\
\hline 17 & Switzerland & & & & & & & & \\
\hline 18 & United & & & & & & & & \\
\hline & Kingdom & & & & & & & & \\
\hline
\end{tabular}

Table B.2

Estimated synthetic control weights (world control group).

\begin{tabular}{|c|c|c|c|c|c|c|}
\hline \multirow[t]{2}{*}{ Country } & \multicolumn{2}{|c|}{ GDP } & \multicolumn{2}{|c|}{ TFP } & \multicolumn{2}{|c|}{ Capital } \\
\hline & ADH & BK & $\mathrm{ADH}$ & BK & ADH & BK \\
\hline Bolivia & 0.1 & 0 & 17.5 & 11.9 & 1.4 & 21.3 \\
\hline Brasil & 0.1 & 0 & 11.5 & 2.1 & 0.7 & 0 \\
\hline Canada & 0.2 & 9.7 & 4.9 & 18.8 & 0.6 & 0 \\
\hline Switzerland & 0.1 & 0 & 0.02 & 0 & 0.2 & 0 \\
\hline D. R. Congo & 10.9 & 4.8 & NA & NA & NA & NA \\
\hline Colombia & 0.1 & 0 & 0.1 & 0 & 1.1 & 0 \\
\hline Costa Rica & 0.3 & 0 & 26.4 & 16.5 & 17.5 & 0 \\
\hline Ecuador & 0.04 & 0 & 0.1 & 0 & 11.4 & 0 \\
\hline Egypt & 21.8 & 25.7 & 6.4 & 8.6 & 10.4 & 26.3 \\
\hline España & 0.1 & 0 & 8.7 & 0 & 0.5 & 0 \\
\hline Guatemala & 0.5 & 0 & 1.1 & 0 & 2.5 & 21.8 \\
\hline Japan & 0.2 & 13.6 & 0.0 & 0 & 0.2 & 0 \\
\hline Kenya & 0.1 & 0 & 0.7 & 0 & 12.4 & 0 \\
\hline Sri Lanka & 0.04 & 0 & 0 & 0 & 5.3 & 0 \\
\hline Luxemburgo & 2.0 & 0 & 0 & 0 & 0.4 & 0 \\
\hline Morocco & 0.03 & 0 & 20.2 & 24.3 & 14.8 & 0 \\
\hline Mexico & 35.0 & 0 & 0.1 & 0 & 0.6 & 0 \\
\hline Trinidad and T. & 9.6 & 17.7 & NA & NA & 8.6 & 0 \\
\hline Uruguay & 0.2 & 28.5 & 1.1 & 0 & 0.5 & 0 \\
\hline Venezuela & 6.9 & 0 & 0 & 0 & 0.4 & 12.3 \\
\hline
\end{tabular}

Note: NA means that data is not available to estimate the weight.

Table for world control only reports countries whose sum of weights $>3$. 


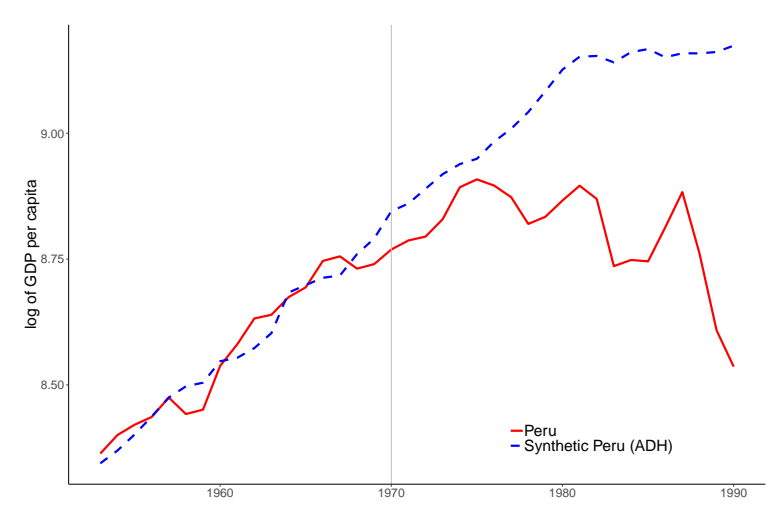

(a) GDP: ADH case.

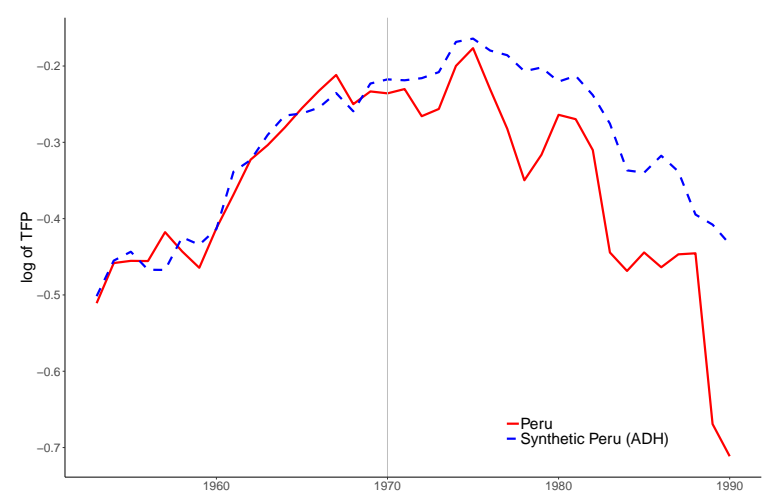

(c) TFP: ADH case.

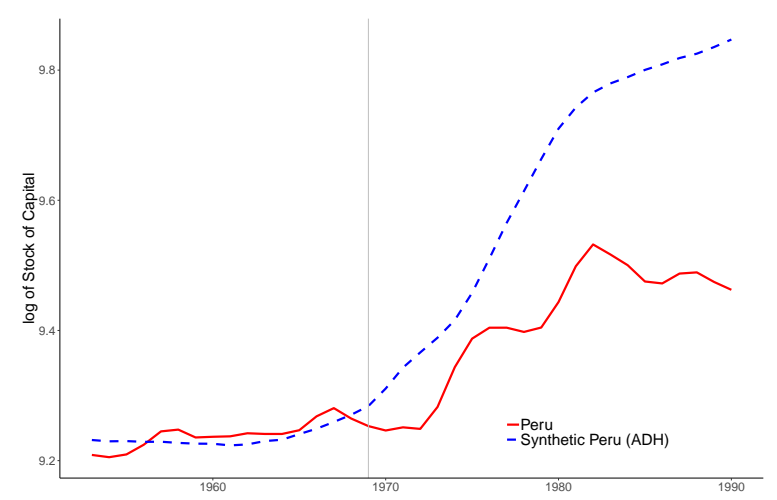

(e) Capital stock: ADH case.

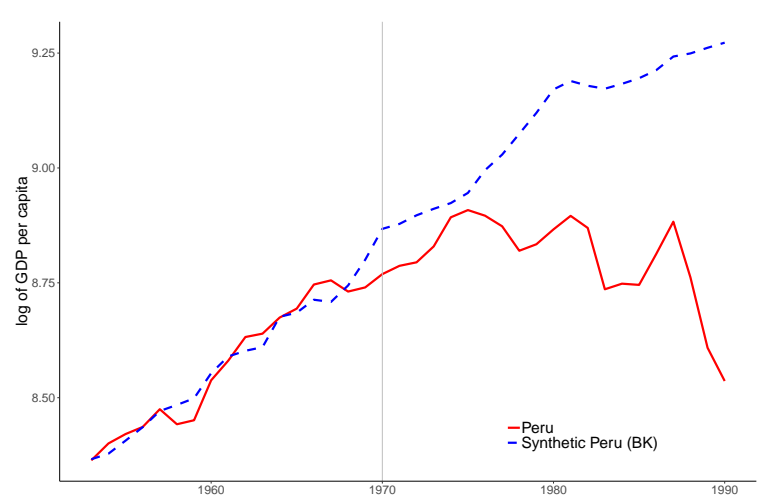

(b) GDP: BK case.

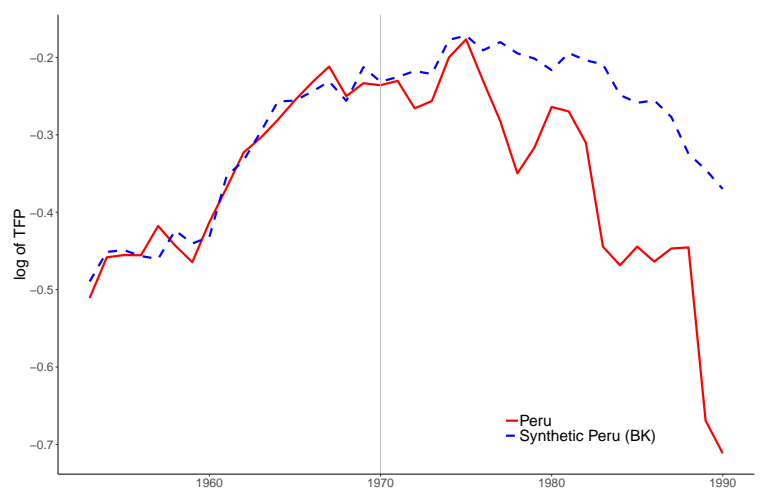

(d) TFP: BK case.

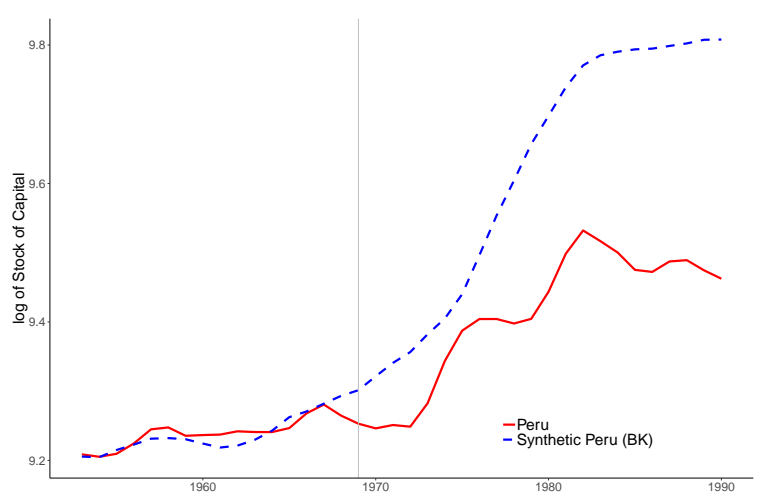

(f) Capital stock: BK case.

Figure B.1. GDP performance in Peru 1953-1990 (world control group). 


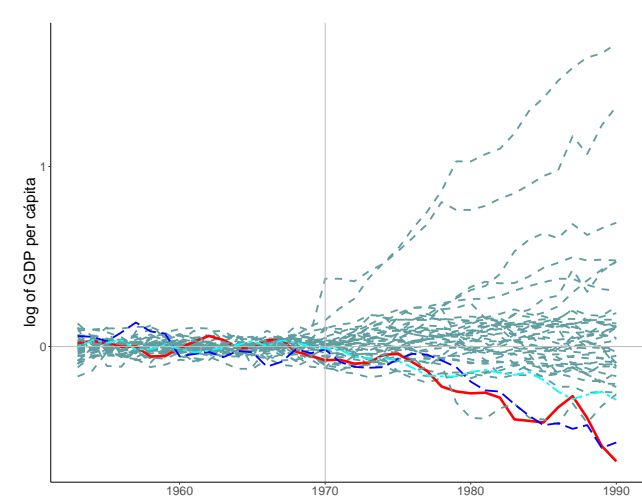

(a) GDP: ADH case.

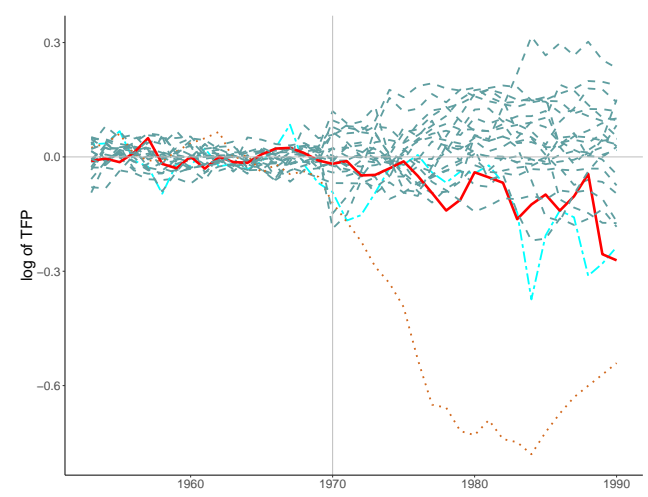

(c) TFP: ADH case.

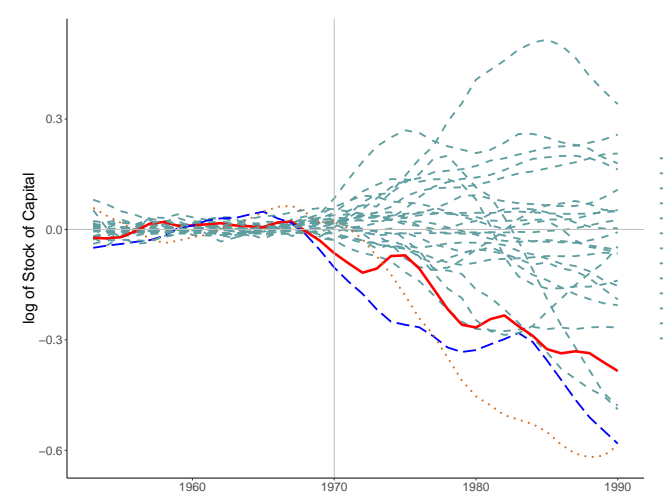

(e) Capital stock: ADH case.

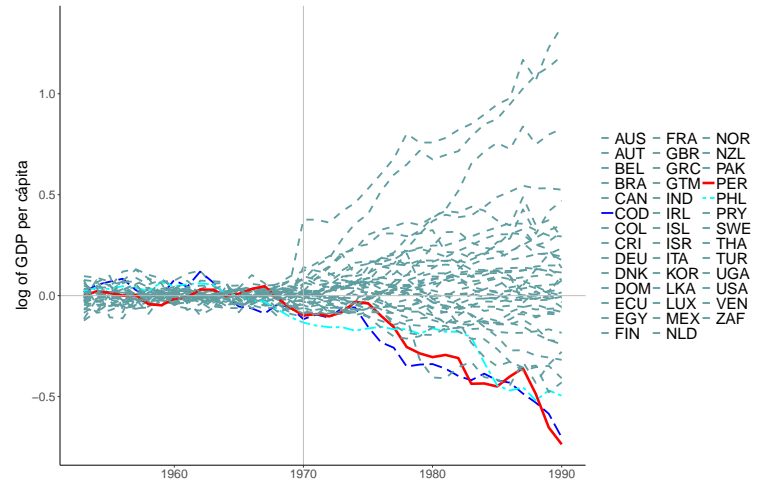

(b) GDP: BK case.

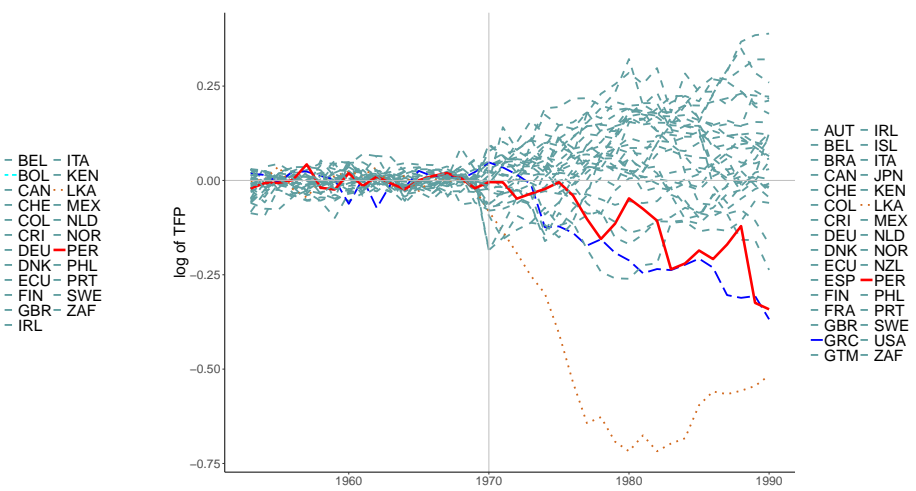

(d) TFP: BK case.

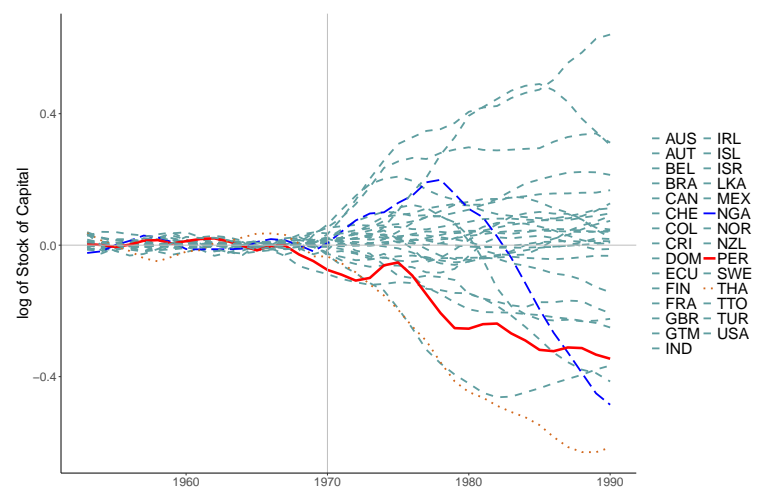

(f) Capital stock: BK case.

Figure B.2. GDP gaps against synthetic counterfactuals: placebo treatments (LAC). 


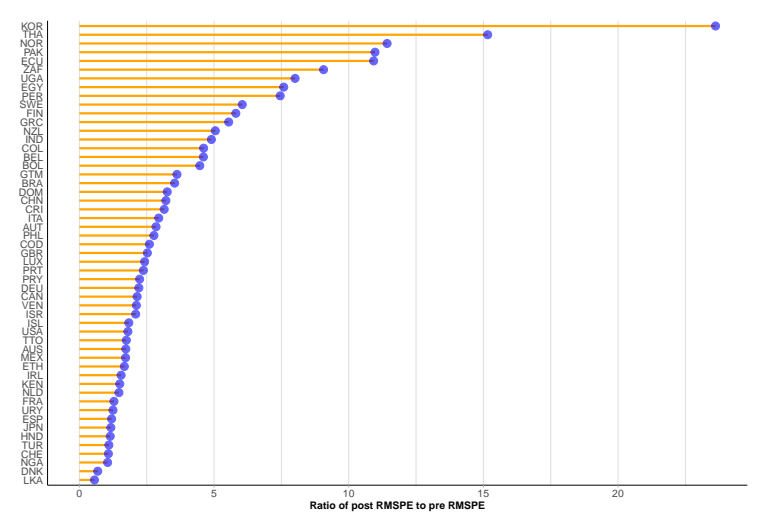

(a) GDP: ADH case.

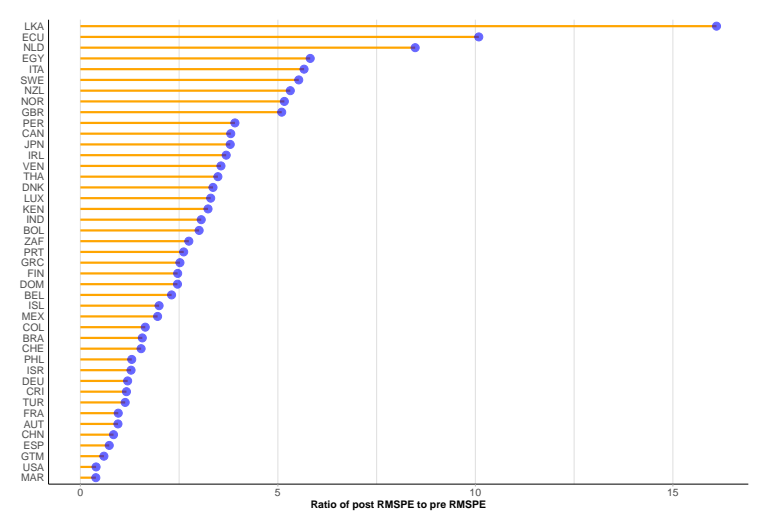

(c) TFP: ADH case.

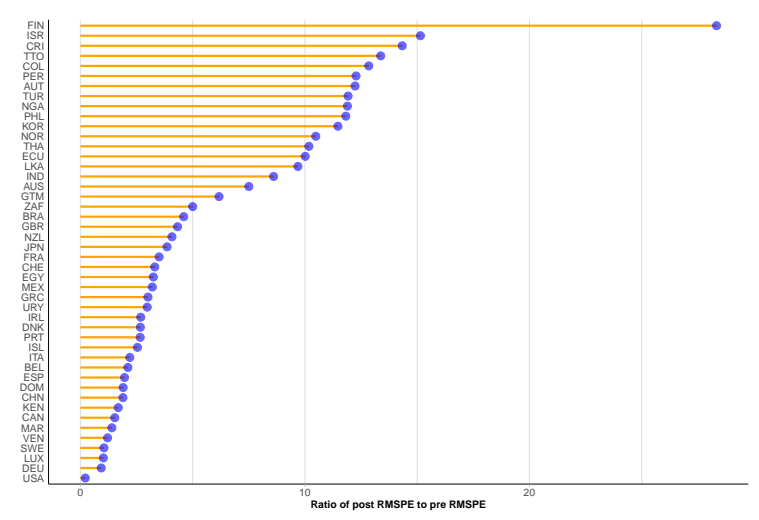

(e) Capital stock: ADH case.

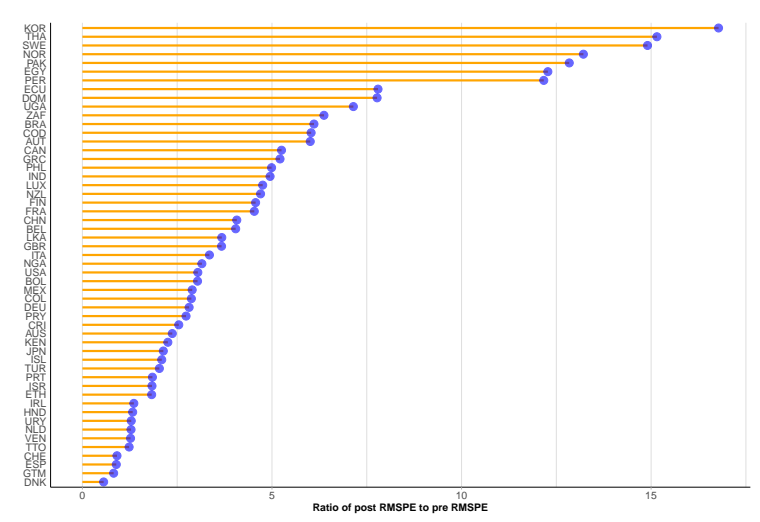

(b) GDP: BK case.

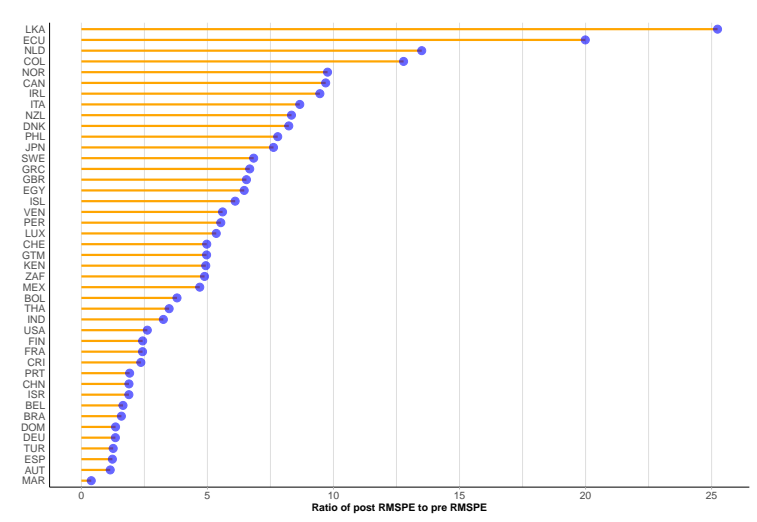

(d) TFP: BK case.

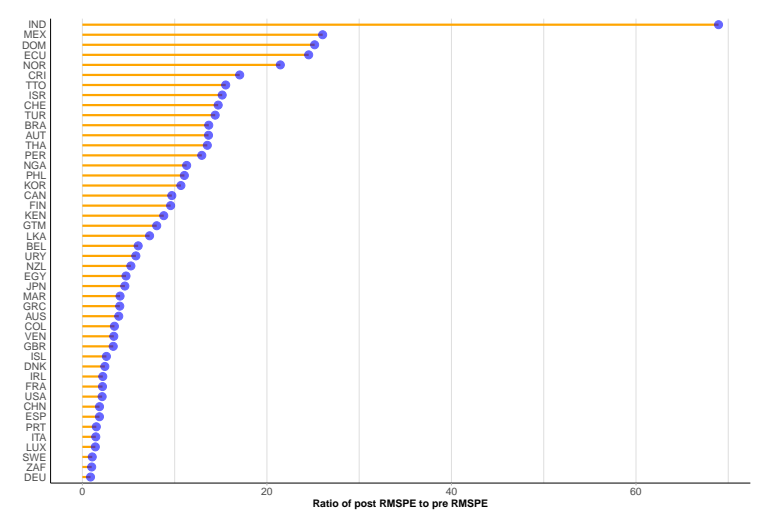

(f) Capital stock: BK case.

Figure B.3. TFP gaps against synthetic counterfactuals: placebo treatments (world). 


\section{Appendix C. Exploration of Treatment Periods}

\section{C.1. GDP per Capita}

The exact year treatment occurred is debatable. General Velasco was in power between October 1968 and August 1975. As explained in section 2, radical economic and social reforms started in 1969 and through 1974.

We run the synthetic control estimations treating each year since 1966 up to 1980 as a possible beginning-of-treatment year. In each case, we compute the mean squared errors of the pretreatment gaps, which ideally should be close to zero for a good weights estimation to build the synthetic control. We also compute post-treatment mean losses for the remaining period until 1990. Post treatment mean losses can be computed all the way up to 1990 or just for the following ten years after treatment. For each instance of post-treatment loss comparisons we work with two cases according to the median or the mean values.

The results are shown in tables C.1 to C.4. Column labeled mean post treatment effect shows that the bigger losses (marked read in each case) appear when we consider a starting year between 1967 and 1973 under the BK efficient computation. Under the ADH computation the starting years can be between 1968 and 1977. On the other hand, the best prediction fit for the pre-treatment period occurs, in all the cases, when we consider 1970, 1971, or 1972 as starting years.

\section{C.2. Total Factor Productivity}

In this case, tables C.5 and C. 6 show the MSE of pre-treatment and post-treatment losses respectively under the $\mathrm{BK}$ and $\mathrm{ADH}$ approaches. Again, a visual inspection favors a treatment year in the range 1969-1972. Figure C.1 shows BK losses are U-shaped centered in 1972. 


\section{Table C.1}

Mean squared errors (MSE) and mean post treatment GDP losses.

\begin{tabular}{cccccc}
\hline & $\begin{array}{c}\text { Treatment } \\
\text { year }\end{array}$ & $\begin{array}{c}\text { MSE pre- } \\
\text { treatment (BK) }\end{array}$ & $\begin{array}{c}\text { MSE pre- } \\
\text { treatment (ADH) }\end{array}$ & $\begin{array}{c}\text { Mean post-treatment } \\
\text { effect (BK) }\end{array}$ & $\begin{array}{c}\text { Mean post-treatment } \\
\text { effect (ADH) }\end{array}$ \\
\hline 1 & 1966 & 0.13 & 0.15 & -3.87 & -22.81 \\
2 & 1967 & 0.12 & 0.14 & -26.15 & -21.97 \\
3 & 1968 & 0.11 & 0.13 & -16.80 & -22.90 \\
4 & 1969 & 0.10 & 0.13 & -19.57 & -23.00 \\
5 & 1970 & 0.09 & 0.14 & -20.21 & -23.10 \\
6 & 1971 & 0.09 & 0.16 & -20.35 & -18.75 \\
7 & 1972 & 0.07 & 0.17 & -21.33 & -20.30 \\
8 & 1973 & 0.11 & 0.13 & -20.16 & -16.18 \\
9 & 1974 & 0.13 & 0.19 & -15.11 & -19.99 \\
10 & 1975 & 0.11 & 0.15 & -15.87 & -16.61 \\
11 & 1976 & 0.10 & 0.14 & -17.57 & -17.72 \\
12 & 1977 & 0.11 & 0.16 & -18.07 & -22.49 \\
13 & 1978 & 0.12 & 0.20 & -18.01 & -21.69 \\
14 & 1979 & 0.20 & 0.34 & -15.94 & -20.42 \\
15 & 1980 & 0.27 & 0.49 & -13.55 & -18.04 \\
\hline
\end{tabular}

Note: Average losses up to 1990. Predictor criteria: median.

\section{Table C.2}

Mean squared errors (MSE) and mean post-treatment GDP losses.

\begin{tabular}{cccccc}
\hline & $\begin{array}{c}\text { Treatment } \\
\text { year }\end{array}$ & $\begin{array}{c}\text { MSE pre- } \\
\text { treatment }(\mathrm{BK})\end{array}$ & $\begin{array}{c}\text { MSE pre- } \\
\text { treatment (ADH) }\end{array}$ & $\begin{array}{c}\text { Mean post-treatment } \\
\text { effect (BK) }\end{array}$ & $\begin{array}{c}\text { Mean post-treatment } \\
\text { effect (ADH) }\end{array}$ \\
\hline 1 & 1966 & 0.13 & 0.15 & -15.91 & -21.09 \\
2 & 1967 & 0.12 & 0.14 & -15.33 & -22.16 \\
3 & 1968 & 0.11 & 0.12 & -16.95 & -22.93 \\
4 & 1969 & 0.10 & 0.13 & -18.62 & -22.01 \\
5 & 1970 & 0.09 & 0.13 & -20.26 & -21.81 \\
6 & 1971 & 0.09 & 0.14 & -20.73 & -21.09 \\
7 & 1972 & 0.08 & 0.15 & -22.19 & -21.70 \\
8 & 1973 & 0.12 & 0.16 & -16.33 & -17.82 \\
9 & 1974 & 0.12 & 0.14 & -14.63 & -18.08 \\
10 & 1975 & 0.11 & 0.13 & -16.49 & -19.98 \\
11 & 1976 & 0.10 & 0.13 & -17.85 & -16.92 \\
12 & 1977 & 0.11 & 0.16 & -18.16 & -22.10 \\
13 & 1978 & 0.12 & 0.20 & -17.98 & -21.17 \\
14 & 1979 & 0.20 & 0.34 & -15.94 & -19.89 \\
15 & 1980 & 0.27 & 0.46 & -13.55 & -18.70 \\
\hline
\end{tabular}

Note: Average losses up to 1990. Predictor criteria: mean. 
Table C.3

Mean squared errors (MSE) and mean post-treatment GDP losses.

\begin{tabular}{cccccc}
\hline & $\begin{array}{c}\text { Treatment } \\
\text { year }\end{array}$ & $\begin{array}{c}\text { MSE pre- } \\
\text { treatment (BK) }\end{array}$ & $\begin{array}{c}\text { MSE pre- } \\
\text { treatment (ADH) }\end{array}$ & $\begin{array}{c}\text { Mean post-treatment } \\
\text { effect (BK) }\end{array}$ & $\begin{array}{c}\text { Mean post-treatment } \\
\text { effect (ADH) }\end{array}$ \\
\hline 1 & 1966 & 0.13 & 0.15 & -7.86 & -9.53 \\
2 & 1967 & 0.12 & 0.14 & -10.87 & -10.43 \\
3 & 1968 & 0.11 & 0.13 & -7.22 & -13.36 \\
4 & 1969 & 0.10 & 0.13 & -10.74 & -14.49 \\
5 & 1970 & 0.09 & 0.14 & -12.74 & -15.99 \\
6 & 1971 & 0.09 & 0.16 & -14.09 & -13.68 \\
7 & 1972 & 0.07 & 0.17 & -15.96 & -15.51 \\
8 & 1973 & 0.11 & 0.13 & -16.31 & -12.84 \\
9 & 1974 & 0.13 & 0.19 & -12.90 & -17.29 \\
10 & 1975 & 0.11 & 0.15 & -14.39 & -14.85 \\
11 & 1976 & 0.10 & 0.14 & -15.73 & -15.63 \\
12 & 1977 & 0.11 & 0.16 & -15.14 & -19.62 \\
13 & 1978 & 0.12 & 0.20 & -14.88 & -18.77 \\
14 & 1979 & 0.20 & 0.34 & -13.95 & -18.52 \\
15 & 1980 & 0.27 & 0.49 & -13.55 & -18.04 \\
\hline
\end{tabular}

Note: Average 10 year losses after treatment. Predictor criteria: median.

Table C.4

Mean squared errors (MSE) and mean post treatment GDP losses.

\begin{tabular}{cccccc}
\hline & $\begin{array}{c}\text { Treatment } \\
\text { year }\end{array}$ & $\begin{array}{c}\text { MSE pre- } \\
\text { treatment }(\mathrm{BK})\end{array}$ & $\begin{array}{c}\text { MSE pre- } \\
\text { treatment }(\mathrm{ADH})\end{array}$ & $\begin{array}{c}\text { Mean post-treatment } \\
\text { effect (BK) }\end{array}$ & $\begin{array}{c}\text { Mean post-treatment } \\
\text { effect (ADH) }\end{array}$ \\
\hline 1 & 1966 & 0.13 & 0.15 & -2.92 & -8.67 \\
2 & 1967 & 0.12 & 0.14 & -4.32 & -10.56 \\
3 & 1968 & 0.11 & 0.12 & -7.19 & -12.94 \\
4 & 1969 & 0.10 & 0.13 & -10.07 & -13.70 \\
5 & 1970 & 0.09 & 0.13 & -12.79 & -14.83 \\
6 & 1971 & 0.09 & 0.14 & -14.41 & -15.20 \\
7 & 1972 & 0.08 & 0.15 & -16.67 & -16.10 \\
8 & 1973 & 0.12 & 0.16 & -13.10 & -14.29 \\
9 & 1974 & 0.12 & 0.14 & -12.33 & -15.36 \\
10 & 1975 & 0.11 & 0.13 & -14.94 & -18.03 \\
11 & 1976 & 0.10 & 0.13 & -15.98 & -14.91 \\
12 & 1977 & 0.11 & 0.16 & -15.23 & -19.18 \\
13 & 1978 & 0.12 & 0.20 & -14.85 & -18.30 \\
14 & 1979 & 0.20 & 0.34 & -13.95 & -18.00 \\
15 & 1980 & 0.27 & 0.46 & -13.55 & -18.70 \\
\hline
\end{tabular}

Note: Average 10 year losses after treatment. Predictor criteria: mean. 
Table C.5

Mean squared errors (MSE) and mean post-treatment TFP losses.

\begin{tabular}{cccccc}
\hline & $\begin{array}{c}\text { Treatment } \\
\text { year }\end{array}$ & $\begin{array}{c}\text { MSE pre- } \\
\text { treatment (BK) }\end{array}$ & $\begin{array}{c}\text { MSE pre- } \\
\text { treatment (ADH) }\end{array}$ & $\begin{array}{c}\text { Mean post-treatment } \\
\text { effect (BK) }\end{array}$ & $\begin{array}{c}\text { Mean post-treatment } \\
\text { effect (ADH) }\end{array}$ \\
\hline 1 & 1966 & 0.15 & 0.44 & -8.54 & 5.14 \\
2 & 1967 & 0.18 & 0.48 & -10.29 & 5.39 \\
3 & 1968 & 0.20 & 0.46 & -11.91 & -0.89 \\
4 & 1969 & 0.21 & 0.54 & -13.92 & -7.46 \\
5 & 1970 & 0.21 & 0.25 & -14.09 & -15.89 \\
6 & 1971 & 0.24 & 0.81 & -15.87 & -7.07 \\
7 & 1972 & 0.22 & 0.75 & -16.91 & -7.24 \\
8 & 1973 & 0.23 & 0.57 & -16.22 & -8.10 \\
9 & 1974 & 0.23 & 0.62 & -15.26 & -6.01 \\
10 & 1975 & 0.22 & 0.54 & -14.27 & -8.25 \\
11 & 1976 & 0.21 & 0.55 & -11.75 & -6.23 \\
12 & 1977 & 0.22 & 0.47 & -10.95 & -6.43 \\
13 & 1978 & 0.23 & 0.44 & -7.43 & -5.72 \\
14 & 1979 & 0.25 & 0.45 & -1.96 & -4.77 \\
15 & 1980 & 0.24 & 0.47 & 0.70 & 1.01 \\
\hline
\end{tabular}

Note: Average losses up to 1990. Predictor criteria: median.

Table C.6

Mean squared errors (MSE) and mean post-treatment TFP losses.

\begin{tabular}{cccccc}
\hline & $\begin{array}{c}\text { Treatment } \\
\text { year }\end{array}$ & $\begin{array}{c}\text { MSE pre- } \\
\text { treatment (BK) }\end{array}$ & $\begin{array}{c}\text { MSE pre- } \\
\text { treatment (ADH) }\end{array}$ & $\begin{array}{c}\text { Mean post-treatment } \\
\text { effect (BK) }\end{array}$ & $\begin{array}{c}\text { Mean post-treatment } \\
\text { effect (ADH) }\end{array}$ \\
\hline 1 & 1966 & 0.14 & 0.37 & -7.05 & -0.67 \\
2 & 1967 & 0.17 & 0.45 & -9.20 & 5.88 \\
3 & 1968 & 0.19 & 0.55 & -10.80 & -2.99 \\
4 & 1969 & 0.18 & 0.53 & -11.68 & -5.04 \\
5 & 1970 & 0.16 & 0.53 & -10.74 & -4.67 \\
6 & 1971 & 0.15 & 0.49 & -11.68 & -4.59 \\
7 & 1972 & 0.15 & 0.48 & -13.42 & -4.95 \\
8 & 1973 & 0.16 & 0.45 & -13.11 & -4.76 \\
9 & 1974 & 0.17 & 0.44 & -12.58 & -4.33 \\
10 & 1975 & 0.18 & 0.44 & -12.40 & -4.48 \\
11 & 1976 & 0.18 & 0.33 & -10.18 & -7.60 \\
12 & 1977 & 0.19 & 0.33 & -9.37 & -3.15 \\
13 & 1978 & 0.21 & 0.29 & -8.25 & -8.12 \\
14 & 1979 & 0.22 & 0.28 & -0.54 & -8.31 \\
15 & 1980 & 0.20 & 0.38 & 2.95 & 1.68 \\
\hline
\end{tabular}

Note: Average losses up to 1990. Predictor criteria: mean. 


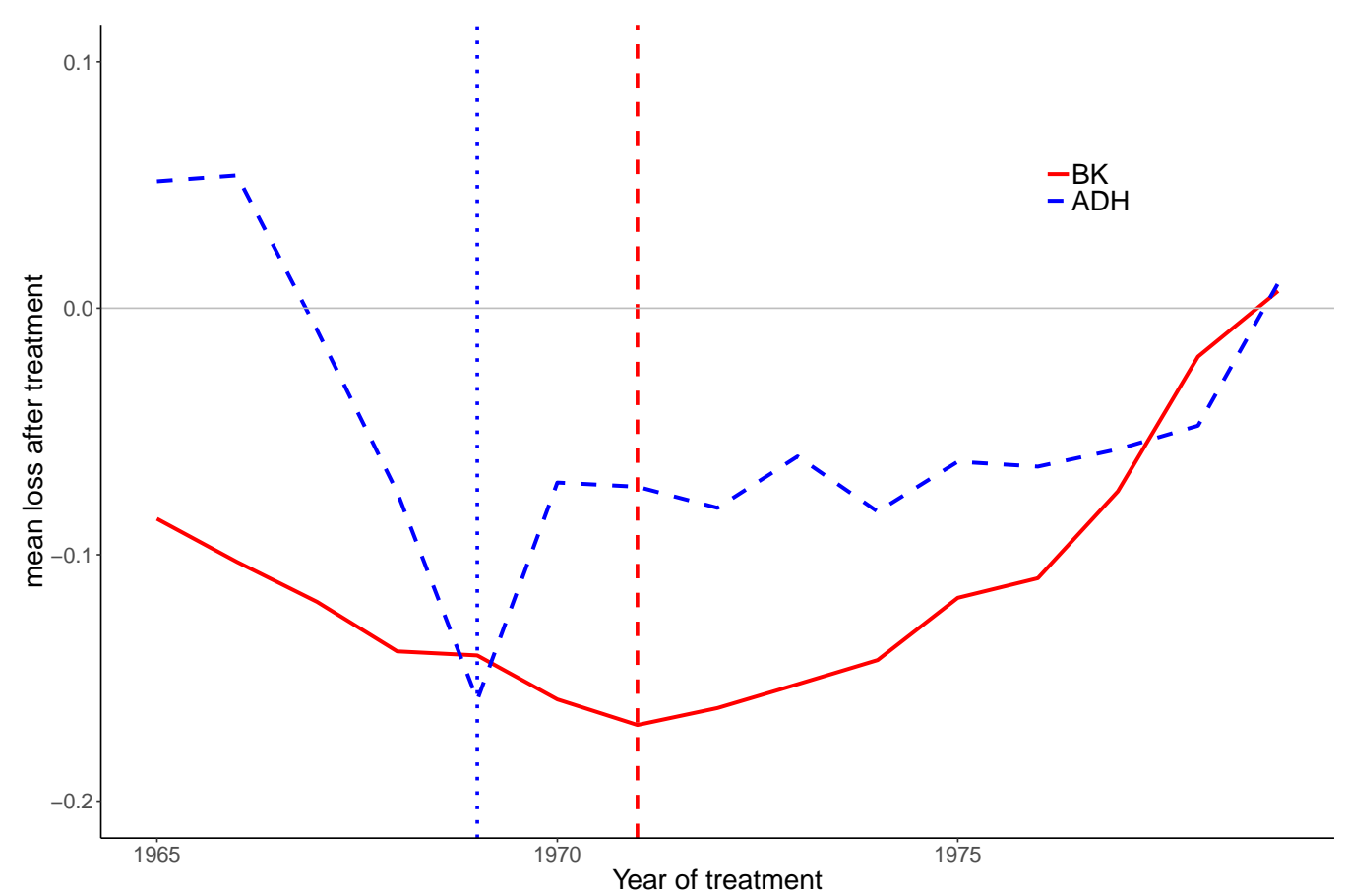

(a) Median predictor criteria.

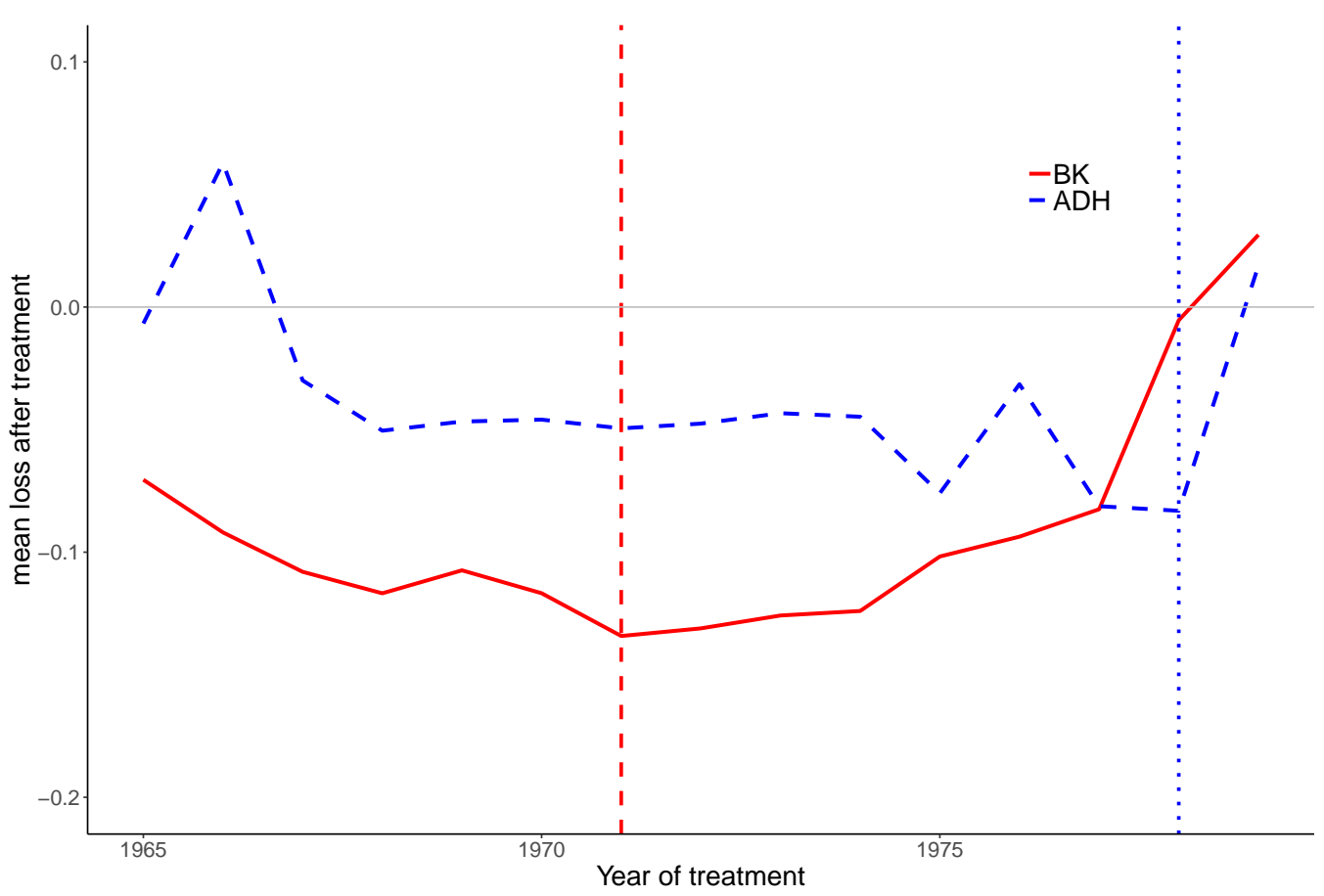

(b) Mean predictor criteria.

Figure C.1. Mean post-treatment TFP losses by possible treatment year. 


\section{References}

Abadie, A., Diamond, A., and Hainmueller, J. (2010). Synthetic control methods for comparative case studies: Estimating the effect of California's tobacco control program. Journal of the American Statistical Association 105(490), 493-505.

Abadie, A., Diamond, A., and Hainmueller, J. (2011). Synth: An R package for synthetic control methods in comparative case studies. Journal of Statistical Software 42(13), 1-17.

Abadie, A., Diamond, A., and Hainmueller, J. (2015). Comparative politics and the synthetic control method. American Journal of Political Science 59(2), 495-510.

Abadie, A., and Gardeazabal, J. (2003). The economic costs of conflict: A case study of the Basque country. American Economic Review 93(1), 113-132.

Abusada, R. (1977). Políticas de industrialización en el Perú, 1970-1976. Revista Economía (Pontificia Universidad Católica del Perú) 1(1), 9-34.

Aguirre, C., and Drinot, P. (Eds.). (2017). The Peculiar Revolution: Rethinking the Peruvian Experiment Under Military Rule. Austin: The University of Texas Press.

Alianza para el Progreso (1961). Carta de Punta del Este. El Trimestre Económico 28(112), 735-764.

Arthur D. Little, Inc. (1960). A program for the industrial and regional development of Peru: A report to the government of Peru. Cambridge, Mass.

Becker, M., and Klößner, S. (2018a). Fast and reliable computation of generalized synthetic controls. Econometrics and Statistics 5, 1-19.

Becker, M., and Klößner, S. (2018b). MSCMT: Multivariate Synthetic Control Method Using Time Series. R package version 1.3.3.

Billmeier, A., and Nannicini, T. (2013). Assessing economic liberalization episodes: A synthetic control approach. Review of Economics and Statistics 95(3), 983-1001.

Cameron, M. A., and Mauceri, P. (Eds.). (1997). The Peruvian laberynth: polity, society, economy. University Park: Pennsylvania State University.

Cavallo, E., Galiani, S., Noy, I., and Pantano, J. (2013). Catastrophic natural disasters and economic growth. Review of Economics and Statistics 95(5), 1549-1561.

Cleaves, P., and Pease-García, H. (1983). State autonomy and military policy making. In A. F. Lowenthal and C. McClintock (Eds.). The Peruvian Experiment Reconsidered. Princeton: Princeton University Press, 209-244.

Cotler, J. (2018). Clases, estado y nación en el Perú. Lima, Peru: Instituto de Estudios Peruanos, 4 th ed.

Espinoza, M., Escobal, J., and Fort, R. (2019). A 50 años de la reforma agraria peruana: nueva evidencia sobre su despliegue temporal y geográfico, y sobre algunos de sus efectos de largo plazo. Paper presented at Seminario Internacional: A 50 Años de la Reforma Agraria. Pontificia Universidad Católica del Perú.

Fitzgerald, E. (1983). State capitalism in Peru: A model of economic development and its limitations. In A. F. Lowenthal and C. McClintock (Eds.). The Peruvian Experiment Reconsidered. Princeton: Princeton University Press, 65-93. 
Gonzales de Olarte, E., and Samamé, L. (1991). Péndulo peruano: políticas económicas, gobernabilidad y subdesarrollo, 1963-1990. Lima, Peru: Instituto de Estudios Peruanos.

Gott, R. (2005). Hugo Chavez and the Bolivarian Revolution. London: Verso.

Grier, K., and Maynard, N. (2016). The economic consequences of Hugo Chavez: A synthetic control analysis. Journal of Economic Behavior \& Organization 125, 1-21.

Hunefeldt, C. (1997). The rural landscape and changing political awareness: Enterprises, agrarian producers, and peasant communities, 1969-1994. In M. A. Cameron and P. Mauceri (Eds.). The Peruvian laberynth: polity, society, economy. University Park: Pennsylvania State University, 107-133.

Hunt, S. (2011). La formación de la economía peruana: distribución y crecimiento en la historia del Perú y América Latina. Lima, Peru: Banco Central de Reserva del Perú, Pontificia Univerisdad Católica del Perú e Instituto de Estudios Peruanos.

Kehoe, T. J., Machicado, C. G., and Peres-Cajías, J. (2019). The monetary and fiscal history of Bolivia, 1960-2017.

Lowenthal, A. F. (Ed.). (1975). The Peruvian Experiment: Continuity and change under military rule. Princeton: Princeton University Press.

Lowenthal, A. F. (1983). The Peruvian experiment reconsidered. In C. McClintock and A. F. Lowenthal (Eds.). The Peruvian Experiment Reconsidered. Princeton: Princeton University Press, 415-430.

Mariátegui, J. C. (1928). Siete Ensayos de Interpretación de la Realidad Peruana. Lima, Peru: Editorial Minerva.

Martinelli, C., and Vega, M. (2018). Monetary and fiscal history of Peru 1960-2010: Radical policy experiments, inflation, and stabilization. University of Chicago, Becker Friedman Institute for Economics Working Paper (2018-63).

McClintock, C., and Lowenthal, A. F. (Eds.). (1983). The Peruvian Experiment Reconsidered. Princeton: Princeton University Press.

Nogues, J. (1986). An historical perspective of Peru's trade liberalization policies of the 80s. World Bank Discussion Paper DRD168.

Quiroz, A. W. (2008). Corrupt Circles: A History of Unbound Graft in Peru. Baltimore: Woodrow Wilson Center Press with Johns Hopkins University Press.

Salazar Bondy, A. (1975). La educación del hombre nuevo: La reforma educativa peruana. Buenos Aires: Paidos.

Schydlowsky, D. M., and Wicht, J. J. (1983). The anatomy of an economic failure: Peru 1968-78. In A. F. Lowenthal and C. McClintock (Eds.). The Peruvian Experiment Reconsidered. Princeton: Princeton University Press, 94-143.

Sheahan, J. (1999). Searching for a Better Society: The Peruvian Economy From 1950. University Park: Pennsylvania State University.

Thorp, R., and Bertram, G. (1978). Peru, 1890-1977: Growth and Policy in an Open Economy. New York: Columbia University Press.

Torres, J. (1982). Protecciones efectivas y sustitución de importaciones en el Perú. Revista Economía (Pontificia Universidad Católica del Perú) 5(10), 9-45. 
Velasco Alvarado, J. (1972). Velasco: La voz de la revolución. Lima, Peru: Ediciones Peisa.

Webb, R. (1991). Prologue to Peru's Path to Recovery: A Plan for Economic Stabilization and Growth, edited by Carlos E. Paredes and Jeffrey D. Sachs. Washington, DC: Brookings Institution.

Zapata, A. (2018). La caída de Velasco. Lima, Peru: Taurus.

Zimmermann, A. (1975). El plan Inca: objetivo, revolucion peruana. Barcelona: Ediciones Grijalbo. 